\title{
Late Pleistocene-Holocene alluvial stratigraphy of southern Baja California, Mexico.
}

José Luis Antinao (*) ${ }^{1,2}$

Eric McDonald ${ }^{1}$

Edward J. Rhodes ${ }^{3}$, Nathan Brown ${ }^{3}$, Wendy Barrera ${ }^{3}$

John C. Gosse ${ }^{4}$

Susan Zimmermann ${ }^{5}$

${ }^{1}$ Division of Earth and Ecosystem Sciences, Desert Research Institute, 2215 Raggio Parkway Reno NV 89512, USA.

${ }^{2}$ National Research Center for Integrated Natural Disaster Management, CIGIDEN, Santiago 7820436, Chile

${ }^{3}$ Earth and Space Sciences Department, UCLA, Los Angeles, CA90095, USA.

${ }^{4}$ Dalhousie Geochronology Centre, Dalhousie University, Halifax, Nova Scotia, Canada B3H4J1.

${ }^{5}$ Center for Accelerator Mass Spectrometry, Lawrence Livermore National Laboratory, CA94550, USA.

(*) Corresponding author: +1 (775) 6737450 .

\section{Abstract}

A late Pleistocene to Holocene alluvial stratigraphy has been established for the basins of La Paz and San José del Cabo, in the southern tip of the Baja California peninsula, Mexico. Six discrete alluvial units (Qt1 through Qt6) were differentiated across the region using a combination of geomorphologic mapping, sedimentological analysis, and soil development. These criteria were supported using radiocarbon, optically stimulated luminescence and cosmogenic depth-profile geochronology. Major aggradation started shortly after $\sim 70 \mathrm{ka}(\mathrm{Qt} 2)$, and buildup of the main depositional units ended at $\sim 10 \mathrm{ka}$ (Qt4). After deposition of Qt4, increasing regional incision of older units and the progressive development of a channelized alluvial landscape coincide with deposition of Qt5 and Qt6 units in a second, incisional phase. All units consist of multiple 1-3 m thick alluvial packages deposited as upper-flow stage beds that represent individual storms. Main aggradational units (Qt2-Qt4) occurred across broad (>2 km) channels in the form of sheetflood 
deposition while incisional stage deposits are confined to channels of $\sim 0.5-2 \mathrm{~km}$ width. Continuous deposition inside the thicker $(>10 \mathrm{~m})$ pre-Qt5 units is demonstrated by closely spaced dates in vertical profiles. In a few places, disconformities between these major units are nevertheless evident and indicated by partly eroded buried soils. The described units feature sedimentological traits similar to historical deposits formed by large tropical cyclone events, but also include characteristics of upper-regime flow sedimentation not shown by historical sediments, like long (>10 m) wavelength antidunes and transverse ribs. We interpret the whole sequence as indicating discrete periods during the late Pleistocene and Holocene when climatic conditions allowed larger and more frequent tropical cyclone events than those observed historically. These discrete periods are associated with times when insolation at the tropics was higher than the present-day conditions, determined by precessional cycles, and modulated by the presence of El Niño-like conditions along the tropical and northeastern Pacific. The southern Baja California alluvial record is the first to document a precession-driven alluvial chronology for the region, and it constitutes a strong benchmark for discrimination of direct tropical influence on any other alluvial record in southwestern North America.

\section{Introduction}

In southwestern North America, dry periods alternated with periods of enhanced effective moisture relative to present-day conditions during the late Quaternary (e.g., Li et al., 2008; Kirby et al., 2013; Roy et al., 2013). Knowledge regarding paleoclimate conditions for this region is primarily derived from the analysis of records from lacustrine sediments, marine cores, and speleothems (Kirby et al., 2012, 2013; Wagner et al., 2010). Alluvial environments are also critical indicators of environmental change related to time-transgressive changes in climate (cf. Bull, 1991). Changes in sediment yield and the timing of regional fluvial aggradation are particularly sensitive to factors such as extreme runoff events and as such can give indications of the hydroclimatological state of a region (cf. Parker, 1995; Huckleberry, 1996; Etheredge et al., 2004; Webb et al., 2008). Extracting paleoclimate histories from alluvial records has been limited, however, because of the difficulties in establishing a well-dated chronological framework for alluvial deposits, as discussed in e.g. Mahan et al. (2007), Miller et al. (2010), and Owen et al. (2014). 
We introduce here a well-dated record for alluvial deposition in the southern portion of the Baja California peninsula, in Northwestern Mexico (Fig. 1). The region has experienced steady Quaternary tectonic activity (cf. Umhoefer et al., 2014; Busch et al., 2011) that has allowed the generation of accommodation space thus favoring the preservation of sediment deposits over time. The area also is a sensitive environment for recording climate oscillations arising from direct tropical influence, outside of the present-day reach of the mid-latitude winter cyclone storm tracks (Fig. 1). The region is also located in a marginal area respect to the core region of the North American Monsoon (Englehardt and Douglas, 2001; Diaz et al., 2008; Arriaga-Ramirez and Cavazos, 2010). Tropical cyclones affect the southern peninsula at least once or twice per year (e.g., Farfán, 2004; Farfán and Fogel, 2007); major intense tropical cyclones affect the area once every three to six years (e.g., Villanueva, 2001; Cavazos, 2002; Antinao and McDonald, 2011). These major tropical storms bring extensive geomorphic impacts associated with fan delta progradation along the coast, alluvial channel erosion and sedimentation (Martínez-Gutiérrez and Mayer, 2004), and erosion in hillslopes, with pervasive rilling and landsliding (Antinao and Farfán, 2013). These impacts are much larger than any of those observed for storms affecting the southern peninsula either as mesoscale convective systems associated with the NAM (without tropical storm influence) or during the winter (frontal storms) as documented e.g., in Villanueva (2001), Martínez-Gutiérrez and Mayer (2004), and Antinao and McDonald (2011).

The benchmark chronology presented here is aimed to understand alluvial deposition and incision in this region, and it is a valuable tie between tropical variability and environmental changes in arid southwestern North America. The morphogenetic sequence introduced here can also be used for comparison and interpretation of paleoenvironmental data for nearby areas in northwestern Mexico and southwest USA. The objectives of this paper are: (1) to describe the morphostratigraphic sequence of accumulated alluvial deposits developed from geomorphological, sedimentological and pedogenetic evidences and supported by radiocarbon, luminescence and cosmogenic dating; (2) to provide an interpretation of its paleoenvironmental significance, and (3) to analyze the alluvial sequence in the context of climate variation recorded globally and regionally for southwestern North America, providing a dynamic explanation for the evolution of alluvial aggradation during the last 70,000 years. 


\section{Study area}

Southern Baja California has experienced moderate tectonic uplift developed in response to rifting since $12 \mathrm{Ma}$ along the Pacific-North American Plate margin (e.g., Fletcher and Munguía, 2000) with relief generation and opening of related basins. The most prominent alluvial basins are La Paz, San Juan, and San José del Cabo (Fig. 1). The basins have been filled by a succession of marine and continental sediments (Martínez-Gutierrez and Sethi, 1997; Fierstine et al., 2001; Busch et al., 2011). Quaternary sediments of the continental El Chorro Formation (Martínez-Gutierrez and Sethi, 1997) top the sedimentary fill, deposited in alluvial fans that radiate from the Sierra La Laguna, northwest of San José del Cabo, or the Sierras Pintada and Las Cruces, east of La Paz (Fig. 1). A late Pleistocene - Holocene age range has been obtained for the uppermost alluvial units correlated with El Chorro Formation near La Paz (Maloney, 2009; Busch et al., 2011; Umhoefer et al., 2014) although no absolute chronology has been developed for the older sediments, or for any of the sediments in the San José basin.

We studied in detail sediments of the above mentioned formation for the two most extensive basins, La Paz and San José (Fig.1). Advantages of these locations include similarities in parent material for regolith and sediments, in thickness of deposits, and in areal extent of alluvial fans. Modern precipitation rates vary between $130 \mathrm{~mm} /$ year in La Paz to $340 \mathrm{~mm} / \mathrm{year}$ in San José del Cabo (Fig. 1), and relief in the catchments supplying these basins varies between $500 \mathrm{~m}$ in La Paz to $1500 \mathrm{~m}$ in the northern San José basin.

\section{Methods}

Mapping and identification of alluvial units was based on analysis of 1:20,000 aerial photographs (INEGI, Mexico), and on Quickbird ${ }^{\circledR}$ and Landsat ${ }^{\mathrm{TM}}$ imagery over a base map produced from a $10 \mathrm{~m}$ DEM (INEGI, Mexico), assisted by field characterization using excavated pits, trenches and natural exposures. Alluvial stratigraphy was characterized along exposed sections to identify buried soils or erosive surfaces that indicate depositional breaks or stratigraphic unconformities. Detailed field descriptions of soil horizons developed on the most stable surfaces were used to provide a relative chronosequence for the deposits and guidance for cosmogenic depth profile and luminescence dating strategies. Sedimentary sections were 
described in detail, relating the exposures to published facies descriptions (Miall, 1996, 2000) and studying its variation along longitudinal or transversal location in the studied fans.

Multiple chronological methods were applied to the various studied sections to build a robust chronological framework. Feldspar Infrared Stimulated Luminescene (IRSL) was used to determine chronology of all units. Samples were taken from below the mixing some biological or pedological processes, which was determined by observing soil textural and structural properties in the upper zones of sampled sections, with field determinations being critical to approve a site for luminescence or cosmogenic depth profile sampling. Single grain IRSL methods on sand (180-220 micron size) were preferred because of expected incomplete bleaching in this alluvial setting (Rhodes, 2011; Brown et al., 2014). Pilot samples were used to establish optimal measurement conditions and fading properties (Huntley and Lamothe, 2001; Brown et al., 2014). Dose recovery experiments were also performed to validate our approach (Wintle and Murray, 2006). Sample preparation was carried out under dim filtered light conditions at the UCLA and DRI Luminescence Laboratories. IRSL measurements were made using TL-DA-20 Risoe automated readers; details on stimulation sources and emission filters can be found in Table S-1 (See Supplementary Data File). A total of 51 samples were selected for this study (Fig. 2). A direct comparison with cosmogenic age estimates was possible using samples from the same pit profiles. A complete methodological description and discussion of the feldspar luminescence approach is described in Brown et al. (2014). Radiocarbon dating was performed on samples obtained from selected sites in younger units. Analyses were carried out by Beta Radiocarbon, Florida. Radiocarbon dates were calibrated using Calib7.1 working with INTCAL13 database (Reimer et al., 2013). Depth-profile measurements of cosmogenic nuclides in vertical sections (e.g., Clapp et al., 2001; Frankel et al., 2007) were used to estimate simultaneously cosmogenic nuclide inheritance as well as exposure age and erosion rate of surfaces (e.g., Brocard et al., 2003; Hidy et al., 2010). ${ }^{10}$ Be isotopes were analyzed in quartz sand (355-710 micron) samples from well characterized alluvial fan surfaces (Fig. 2), with on-site sieving to optimize sample amount according to expected AMS ratios based on preliminary estimates of age (e.g., Gosse and Phillips, 2001). Initial preparation of samples for cosmogenic analysis was performed at the Quartz Purification Facility at DRI. ${ }^{10} \mathrm{Be}$ was isolated from pure quartz using chromatographic columns and chemical extraction at the Dalhousie Geochronology Centre. Resulting BeO targets were analyzed at Lawrence Livermore National Laboratory 
(LLNL). We use a constrained Monte Carlo approach to analyze TCN depth profile results, coded in Matlab®. This code allows explicit input of geologic variables as surface erosion rate and subsurface density and their probability distributions, reflecting uncertainties from field and laboratory analyses (Hidy et al., 2010), in order to model reported surface ages.

\section{Results}

\subsection{Soils data and geochronology}

Time-related differences in composition, sedimentology, surface morphology and major soil properties obtained from 21 described soil profiles for the major alluvial units identified was compiled and integrated into a summary table (Table 1). Details about location of all soil pits, sections and geochronology sampling sites are presented in Table S-2 (Supplementary Data File). Geochronology results for luminescence dating are shown in Table 2, for radiocarbon dating in Table 3, and for the two cosmogenic depth profile chronologies in Tables 4 and 5. The temporal distribution of the six new IRSL ages and the C-14 and cosmogenic data is in agreement with that of the chronology presented in Brown et al. (2014), and of previous work in the La Paz and San Juan area (Maloney, 2009; Busch et al., 2011; Umhoefer et al., 2014). Further details on interpretation of specific sites are presented below in the respective unit description.

\subsection{Characteristics of alluvial units}

Six alluvial morphostratigraphic units spanning deposition from $\sim 120$ ka to the present were identified in both studied basins. These units are described in detail below.

\subsubsection{Unit Qt1}

Alluvial unit Qt1 appears in the extreme northern and southern portions of La Paz basin. In the north, unit Qt1 occurs as isolated patches remaining on slopes north and northeast of La Paz, commonly within protected round-topped ridgeline remains in an example of ballena topography (Driscoll et al., 1984) either overlying Oligocene fluvial conglomerates along the coast (Fig. 3A) or entrenched, as in Coyote Valley (Fig. 2). Deposits assigned to Qt1 appear in 
the southern portion of La Paz basin, outside of the mapped area (Fig. 2), composing most of the moderately dissected and faulted fan morphology near La Matanza (Fig. 1), halfway between La Paz and Todos Santos. In this area, the soil has been partially stripped, exposing a $\sim 1 \mathrm{~m}$ thick well cemented and indurated Bqm horizon, with evidence of silica precipitation in the matrix of pebbly sand layers (Fig. 3B).

Polymictic rounded gravels are prevalent in the few natural exposures and road cuts that expose unit Qt1 across Coyote Valley, in northern La Paz basin. The sediments in this part of the basin are mostly derived from nearby Oligocene conglomerates bearing volcanic lithologies, as opposed to the intrusive lithologies that dominate all rest of sediments in this study.

Sedimentology of this unit is dominated by gravels and sands with horizontal planar bedding and imbrication indicating a northward flow in the Coyote Bay exposures (Fig. 3A), with similar flow direction as the present-day Coyote Creek drainage. A soil section was excavated in a preserved surface of the Qt1 alluvial deposit on top of a pronounced terrace that is $\sim 15 \mathrm{~m}$ above sea level along the western margin of Coyote Bay (pit REC-1; Fig. 2; Fig. 3C). This terrace extends to the east of Coyote Bay, but in this area the upper alluvial level is missing in the section and the soil is directly developed over littoral deposits (Fig. 3A). The alluvial deposit in western Coyote Bay is $\sim 5 \mathrm{~m}$ thick over a coral debris-covered marine abrasion platform, in turn developed over more alluvial gravels. The soil here is deep (> 3m) and well-developed, and has formed in sandy-gravel alluvium with a strongly-developed Bt horizon that has a well-defined prismatic and angular blocky structure, a 5YR hue, and a clay loam texture. The soil also has a strongly developed Bk horizon with stage III-IV carbonate that is weakly cemented in places (Table 1; Fig. 3C). The source of the carbonate is probably from the in-situ dissolution of marine calcareous materials (e.g. shells, corals) that locally comprise the base of the unit. The Qt1 soil is the only soil described that has pedogenic carbonate. The soil of the Qt1 terrace is also the best developed soil we have found in the study area that remains preserved at the surface (Table 1). In places (e.g., near Tecolote) however, the upper horizons of soil in this unit have been completely stripped and only the harder Bk horizon remains.

Coral rubble and beach pebbles appear interbedded in the lower portion of the studied Qt1 deposits at West Coyote Bay. Nearby, at Tecolote, the coral rubble has been dated by U/Th to $146 \pm 9,135 \pm 6 \mathrm{ka}$ (Szabo et al., 1990) and 123 $\pm 6 \mathrm{ka}$ (Sirkin et al., 1989). Similar deposits on the western La Paz Bay (outside of the area covered by Fig. 2) have been dated to 128-130 ka 
(Forbis et al., 2004), all temporally related to a marine highstand during the interglacial Marine Isotope Stage (MIS) 5e. We therefore interpret the age of the Qt1 deposits to be $\sim 120-130 \mathrm{ka}$ (the age of marine highstand during interglacial stage 5e) because of the lack of soil formation in the well-preserved coral rubble that is interstratified within the alluvium. This stratigraphic relation indicates that limited time occurred between exposure of the deposits of the marine incursion and subsequent burial by the alluvium. Deposition of unit Qt1 in northern La Paz

probably ended shortly after MIS 5e. We correlate the southern with the northern La Paz Qt1 deposits mainly based on soil development.

\subsubsection{Unit Qt2}

Alluvial unit Qt2 is an extensive deposit, especially along the southern La Paz basin and the northern San José basin (Fig. 2). Unit Qt2 sediments appear in most places directly on top of Pliocene sandstones in both basins, and is inferred to be stratigraphically on top of Qt1 deposits. The contact with the Pliocene sediments can be observed at the foot of hillslopes along the integrated drainage network that has developed on Qt2. In proximal fans, thickness of Qt2 sediment can reach up to 30-40 m. (Fig. 3D). The thick alluvial packages of Unit Qt2 produce prominent fans, commonly inset by or overlain with younger alluvial units (Fig. 2, 3E).

Extensive erosion of Unit Qt2 has created ballena topography in places. Most Qt2 sediments are derived from highly grussified Cretaceous granites, granodiorites and tonalites. In the northern edge of the San José basin some of the Qt2 sediments are derived from gneisses and quartzschists, and the sediments display a bouldery-blocky appearance (Fig. 4). Cobbles and pebbles are the dominant grain sizes and are deposited as horizontal, lenticular or planar crossbedding sets. Occasional pebble sand bars and medium sand lenses appear suggesting conditions of reduced energy in the flow. Planar bedding is the most common sedimentary feature, along with low-angle cross-bedding, with foresets and backsets (Fig. 4), and gravel bars. In some of the coarser facies in this unit (e.g., in the northern San José basin), pool-and-chute features are preserved in the sediments (Fig. 4).

Two sections were cleared and deepened on a quarry excavated at Ejido Alvaro Obregón, La Paz Basin (Fig. 2). The soil formed in Unit Qt2 consists of a well-developed profile that has formed in sandy-gravel alluvium, is nearly $3 \mathrm{~m}$ deep, and has a strongly-developed Bt horizon 
with prismatic and angular blocky structure, a silty-clay loam texture, and a reddish hue 2.5YR (Table 1; Fig. 5E). A cosmogenic depth profile from one of the described soils (EAO-3; location

in Fig. 2) yielded an age of 57.6-17 ${ }^{+19} \mathrm{ka}$ (2-sigma) (Fig. 5). Similar IRSL ages were obtained by sampling the same profile site at $2.7 \mathrm{~m}(57.2 \pm 4.4 \mathrm{ka})$, and in a section $3 \mathrm{~km}$ south of the profile

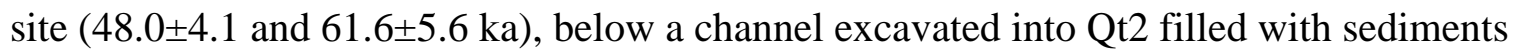
grading to Qt3 deposits (Fig. 3E). In San José, deposits mapped as Qt2 based on their soil

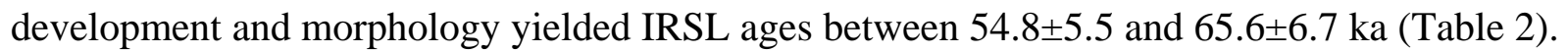

\subsubsection{Unit Qt3}

Alluvial unit Qt3 is present across most of the study area either exposed at the surface or overlain by younger alluvial units and exposed by stream or road cuts. As in the case of Qt2, sediments for unit Qt3 are mostly derived of highly grussified Cretaceous granites, from low relief areas in La Paz basin, or from higher relief areas in San José. Locally, catchments with gneiss and schist bedrock develop bouldery deposits as in northern San José. Unit Qt3 sediments in places form a thick stack $(\sim 10-20 \mathrm{~m})$ of sediment packages separated by weakly developed oxidation zones (Fig. 6A). In some areas, the top of Qt3 is covered by thin $(<5 \mathrm{~m})$ layers of Qt4 sediments; the best example of this superposition is in San Lázaro (Figs. 2C, 6B, C), north of San José del Cabo. In areas closer to the Holocene and modern-day active drainage network, Qt3 can be covered by Qt5 deposits filling channels following closely the direction of drainages (Fig. $3 \mathrm{E})$.

Coarse pebbles and cobbles in horizontal, lenticular or planar crossbedding sets dominate the sedimentology of the Qt3 sections. Pebble-sand sets appear in 10-20 $\mathrm{cm}$ packages displaying normal grading, with conformable or slightly erosive boundaries. The finer portion of these packages is generally composed of medium sand. Planar bedding is the most common sedimentary feature, along with low-angle cross-bedding, with foresets and backsets, and gravel bars. The presence of transverse ribs (transverse gravel bars; cf. Allen, 1982), with boulders at the top of $2 \mathrm{~m}$ packages suggest very energetic flow and development of standing waves (Fig. 4). Lenticular and planar crossbedding sets in places develops characteristic antidune bedsets of wavelengths up to 10-15 m. Event packages form sequences 1-2 $\mathrm{m}$ thick that can stack up to tens of meters separated by well-defined erosional boundaries noted above. Maximum observed thickness is about 20-30 m, especially in San José basin (San Lázaro, La Palma, Fig. 2, 6A). 
Paleocurrent distribution from imbrication measurements indicates flow in a similar fashion to the present-day fluvial conditions associated with floods generated by tropical storms. Trough cross-bedding only appears towards the distal sections of the fans.

Soils formed in Unit Qt3 are deep (2.4-3.3 m) moderately developed soils that have a moderately developed Bt horizon with weak prismatic to moderate subangular blocky structure and 10YR to 8.75YR hues (Table 1). The soil profiles examined in the San José basin are slightly better developed relative to soils in the La Paz basin due to a precipitation gradient that

increases to the south. A cosmogenic ${ }^{10} \mathrm{Be}$ profile age of $37.1_{-12}^{+13} \mathrm{ka}$ (2-sigma) was obtained in pit EAO-2 (Fig. 2), excavated at the southern portion of La Paz basin (Fig. 5). IRSL ages in the same pit yield slightly younger dates when corrected for fading (31.0 \pm 3.5 and $26.4 \pm 3.4 \mathrm{ka})$. All IRSL ages in San José basin match the depth-profile cosmogenic age range in the above mentioned EAO-2 pit $(30.6 \pm 2.8$ to $37.0 \pm 2.9 \mathrm{ka})$.

\subsubsection{Unit Qt4}

Alluvial unit Qt4 is exposed as an extensive unit with outcrops comprised of depositional layers 5-10 m thick that overlie sediments of unit Qt3 in San José (e.g., Arroyo San Lázaro, Fig. 6B-C). In the Cajoncito alluvial fan in La Paz, 10-15 m of exposed section is partially covered by 1-3 m of Qt5 sediments (Fig. 6E). In the rest of northern La Paz basin, most of the unit appears to be blanketed by a layer of Qt5 deposits.

Most sections are dominated by coarse sand and fine pebble sheets with varying proportions of coarse pebbles and cobbles in horizontal, lenticular or planar crossbedding sets which in places form characteristic antidune bedsets of wavelengths up to $10 \mathrm{~m}$. Planar bedding is the most common sedimentary feature (Fig. 6B,E), along with low-angle cross-bedding, with foresets and backsets, and gravel bars. Pebble-sand sets appear in 10-20 cm packages displaying normal grading, with conformable or slightly erosive boundaries. The finer portion of these packages is generally composed of medium (rarely fine) sand. The packages form sequences 1-2 $\mathrm{m}$ thick that stack up to tens of meters. It is rare to observe more than $\sim 10-15 \mathrm{~m}$ of cumulative deposition in section, and clear stratigraphic boundaries appear beyond this thickness with Qt3 below (especially in San José ) and Qt5 on top (especially in La Paz). Palaeocurrent distribution from imbrication measurements indicates channel networks that drained in similar fashion to the present-day conditions. 
The Qt4 alluvium has a stable soil on the surface (e.g., in San José) or is overlain by the younger unit Qt5 (e.g., Cajoncito, La Paz). Unit Qt4 is identified in the field due to a deep (>2.5 m) moderately developed soil profile that is easily distinguishable from soils developed on the Qt5 or Qt3 deposits. Four soil profiles with similar morphology were described (e.g., Table S2 in the Supplementary Information Dataset, pits SJ1, SJ2, ST1, ST2). The typical unit Qt4 soil (Table 1) has formed in sandy-gravel alluvium (Fig. 6C-D) and is a deep, moderately developed soil with either a weakly developed Bt horizon or a distinct Bw horizon. The soil contains abundant faunal burrows and root casts up to $150 \mathrm{~cm}$ deep. IRSL ages on Unit Qt4 range from 18 to $6 \mathrm{ka}$ (Table 2), although most of the deposits are in the range 15-11 ka. The upper $2 \mathrm{~m}$ of several dated pit and section profiles (e.g., SJ2; Fig. 6D) have younger (7-3 ka) ages than the bulk of the deposits sampled along natural sections. Ages less than $\sim 7 \mathrm{ka}$ from these profiles are most likely due to unrecognized bioturbation and the downward mixing of soil from the surface rather than representing a separate overlying Qt5 deposit. The overall depth and structure of the Bt horizon in the upper $2.5 \mathrm{~m}$ at all four sites is very similar, there are no clear signs of fluvial truncation and/or deposition of younger sediment within any of the Qt4 sections examined, and the soils on unit Qt4 within the uppermost 1.5-2 m are deeper and distinctly better developed than the Qt5 soils (Table 1), as discussed below. By comparison, the degree of soil development indicates that a distinct Qt5 layer overlies the Qt4 in the La Paz basin, indicating that the Qt4 surface was subsequently covered by Qt5 (Fig. 6E).

\subsubsection{Unit Qt5}

Unit Qt5 is associated with the drainage network linked to present-day arroyo development, in two characteristic settings. First, it appears infilling 0.5-2 km wide channels with terraces that are about 2-3 m above modern channel level (Fig. 7A-B). Second, unit Qt5 in La Paz basin overtops channel banks and blankets Qt4 sediments with a variable thickness of sediments (Fig. 7E), aggrading to the same level than unit Qt6 in distal alluvial fan positions south of the city of La Paz. Units Qt5 and Qt6 are difficult to separate when viewing imagery and criteria for distinguishing them are based on their position in the present day landscape, type of vegetation cover, and relative differences in soil development. Without geochronological control of every section, misidentification is possible. 
Coarse sand and fine pebble sheets dominate the sediments, in horizontal, lenticular or planar crossbedding sets. In La Paz, cobbles and pebbles occur rarely and are restricted to the base of individual packets, while in San José cobbles and boulders are more common, especially towards the north, where overall deposits are coarser. Pebble-sand sets appear in 10-20 cm packages displaying normal grading, with conformable or slightly erosive boundaries. The finer portion of these packages is generally composed of medium (rarely fine) sand. The packages form sequences 1-2 $\mathrm{m}$ thick that appear stacked, separated by well-defined erosional boundaries from Qt4 or older units (e.g., Fig. 3D), and with cumulative thickness of maximum 5-6 m (e.g., east of La Paz, section CAN-1). Planar bedding is the most common sedimentary feature, although massive sediment packages and planar cross-bedding have been observed (Fig. 7C-D).

Soil stratigraphy indicates that unit Qt5 can be subdivided into 2 distinct alluvial units (Table 1) and that each of these soils is readily differentiated from soils on either the Qt4 or Qt6 surfaces. Units Qt5o and Qt5y have however not been differentiated in our mapping (Fig. 2) due to a lack of correlation between surface morphology, position in the landscape and the above mentioned features. It is also possible that unit Qt5o is expressed as a separate deposit only in La Paz. Soils on the Qt5o (older) surface are nearly $1.5 \mathrm{~m}$ thick and have a moderately developed $\mathrm{Bw}$ horizon with weak to moderate subangular blocky structure, loamy sand texture, and $10 \mathrm{YR}$ hues. By comparison, the soils formed on unit Qt5y (younger) are less than $0.6 \mathrm{~m}$, have a weakly developed Bw horizon, with weak subangular blocky structure in a few horizons, and a sandy texture. The Qt5 unit chronology ranges between 2.5-6 ka, which we correlate to the soildefined unit Qt5o (e.g., Mesquitito, Bonfil bank, Table 2, Fig. 7D), to 0.3-0.4 ka, which is correlated to unit Qt5y (channel inset terraces in La Paz and San José). The latter chronology overlaps with unit Qt6 (Fig. 7B). In the Mesquitito ${ }^{14}$ C/IRSL profile (Fig. 2, 7D), Qt4 and Qt5 units are separated by a buried soil with a weak Bw, corresponding also to the change observed in the absolute chronology.

\subsubsection{Unit Qt6}

Unit Qt6 appears in natural sections and man-made excavations along the drainage network associated with recent arroyo development. Its largest extension is reached in the distal portions of alluvial fan complexes in La Paz basin. In San José basin this unit is restricted to 
channel infilling (Fig. 7A-B). Two settings can be distinguished. One is the active channels, which are occupied by tropical cyclone or other summer precipitation-derived runoff at least once or twice per year, mostly near the mountain fronts (Fig. 7B). The other is vegetated bars and 1-2 $\mathrm{m}$ high terraces along the channels that are completely flooded and reshaped once every three to five years when a major tropical cyclone affects the region (e.g., Hurricane Juliette in 2001; Farfán, 2004). Occasionally, flooding from large tropical storms has spilled sediment over channelized banks, as it happened during hurricane Liza in 1976 in La Paz basin (Fig. 8). The streamflow during this storm bifurcated and occupied the northernmost channel of Arroyo Cajoncito when entering the urban area of La Paz, funneled by two nearby hills, destroying a retention dam. Along the channel banks, in the apical fan area, more than three meters of sediment, including large cobbles and boulders, along with assorted anthropogenic material (glass shards, concrete pieces, rubber tire pieces, tin cans) were deposited (Fig. 8A,D). At least a meter of sand and coarser sediment was deposited along specific alluvial channels inthe urban area of La Paz, which together with the flooding caused the death of around 600 people (Villanueva, 2001). Active, channelized runoff over the surface of alluvial units Qt4 and Qt5 has been documented by aerial photographs taken shortly after the event east of La Paz (Martínez Gutiérrez and Mayer, 2004), indicating that infiltration capacity was exceeded during this storm even for these sandy younger units.

Characteristic horizontal bedding is observed in sediments of Qt6 (Fig. 8B, D). Upstream and downstream dipping low-angle planar cross-bedding in antidune bedforms with 2-4 m wavelength is also observed particularly near the base of the Liza deposit in Cajoncito, along with massive gravels (Fig. 8C). Sediments mapped as Qt6 have minimal soil development which primarily consists of a weak accumulation of organic matter and soil mixing from faunal and flora bioturbation. Luminescence chronology indicates 1.0-0.1 ka for Qt6 sediments along the channel and the lowest terrace in both basins (Table 2), even for sediments deposited during hurricane Liza (Fig. 8C).

\section{Discussion}

\subsection{The alluvial chronosequence}

Alluvial deposition in the study area took place along fans radiating out of the mountain fronts defined by La Paz and San José faults (Fig. 1). The alluvial deposits exhibit sequences 
that are regional in scope and comparable to alluvial deposits in other areas of southwestern North America, like the northern Sonoran desert (cf. Bull, 1991; Spelz et al., 2008; Armstrong et al., 2010), where Pleistocene alluvial fans have been interpreted as developing in response to climate variation (Bull, 1991). Sedimentary units in the study area correlate across the two studied basins (Fig. 2), indicating a common mechanism of generation, independent from both the tectonic evolution of specific uplifted ranges (Sierra La Laguna and Sierra La Pintada) and present day differences in total precipitation. Similarity in alluvial aggradation timing for the two different basins also suggests a common response to a driver other than base level change (sea level in this case). If sea level were an important driver (more than local expression of climate), active deposition would appear in La Paz basin during the low sea level period associated with the global last glacial maximum (LGM). We note that the shelf in this area has a much lower slope than the overall alluvial plain (cf. Del Monte-Luna et al., 2005) and therefore any fall in sea level would have caused aggradation (cf. Summerfield, 1985; Leckie, 1994), not incision. The response in San José during the LGM on the other side, should have been of a deep incision of previous surfaces (Qt3, Qt2), given that the shelf has a short, steep slope. Deep channels are excavated, but they not only incise Qt2 and Qt3 units but also thick Qt4 deposits blanketing previous units, and therefore these channels postdate the LGM. Incision therefore is at least post9-11 ka in both basins (Qt4). In La Paz, incision probably only happened after Qt5o (5-6 ka).

Regional stratigraphic units can therefore be interpreted as pronounced aggradational events (Fig. 2) related to time-transgressive changes in climate. Cycles of increased sedimentation and subsequence channel incision produced distinct, commonly extensive geomorphic surfaces. In most places these surfaces are preserved today, although in places sediments of older units are buried by thin mantles of younger units, as in Qt5 over Qt4 in La Paz (Fig. 2, 6E, 7D), or in Qt4 over Qt3 in San José (Fig. 2C, 6B). Evidence for periods of deep incision is apparent between Qt4 and Qt5 (up to 30-40 m in San José, 10-20 m in La Paz), and Qt5 and Qt6 in La Paz ( 10 m). Between Qt2 and Qt3 in San José basin, channel incision and sediment burial is recorded without the impressive $(>20 \mathrm{~m})$ incision characteristic of the channels where younger (Qt4, Qt5) units are incised. Paleochannels interpreted as developed during Qt3 appear nevertheless in similar position and orientation as present-day channels (Fig. 2). Synchronic incision in both basins suggests that tectonics and sea level change (as base level change) are not primary drivers of this incision. We propose instead, as a working hypothesis, 
that incision of fan surfaces in this area is caused primarily by a reduction in the amount of sediment produced and supplied by hillslopes between major aggradation periods, linked not only to a potential reduction in runoff but also to a climatically induced reduction in sediment production under relatively colder and drier conditions (cf. Hidy et al., 2014).

\subsection{Evidence for intense rainfall events}

A difference between the alluvial sequence analyzed in this study and that in the northern Sonoran desert however is the lack of bar and swale topography commonly observed in the Sonoran and Mojave deserts (cf. Bull et al., 1991; Miller et al., 2010). Bar and swale topography is not prevalent on the surface morphology for most of the alluvial fan surfaces, except in reduced areas of the youngest (Qt5-Qt6) deposits. Bioturbation in both the higher alluvial surfaces in La Paz and across the entire San José basin could have caused reduction of the smallscale relief. We observe however that the sedimentology of the units does not support any braided stream activity in the fans, as noted in the Lower Colorado (Bull, 1991). Trough crossbedding, for example, was only observed in one place in unit Qt3, restricted to the lower portion of the fan units near Caduaño (Fig. 2).

Present-day climatology indicates that extreme rainfall events in the region (i.e., P95 events, those whose total precipitation is above the $95 \%$ of all events) leave a geomorphic legacy of erosion, flooding and landsliding (Martinez-Gutierrez and Mayer, 2004; Raga et al., 2013; Antinao and McDonald, 2011; Antinao and Farfán, 2013), and they are all derived from tropical cyclones (Englehardt and Douglas, 2001; cf. Diaz et al., 2008). Similarity in sedimentology between historical (Qt6) and older units (Table 1B) is arguably proof that deposition of older units was achieved by storms of at least similar intensity and duration, and that the regionally high-intensity rainfall associated with tropical cyclones provides the source for such energetic and prevalent flow, as compared e.g., with rainfall from convective sources during summer time and associated with the NAM only.

A quantitative estimate of instantaneous paleodischarge was performed using techniques developed by Kennedy (1961, 1969) and Foley (1977), using measured wavelengths in preserved antidune bedforms of upper-flow regime lithosomes, and estimates of channel widths based on directly measured or similar medial or apical channel dimensions in the basin (Table S-3). Instantaneous discharge estimates average $\sim 10,000 \mathrm{~m}^{3} \mathrm{~s}^{-1}$ e.g., for sections in San José Qt3 unit 
(Fig. 4; Table S-3), approximately one order of magnitude higher than instantaneous discharges from recent storm hydrographs in the same catchment (e.g., those measured during hurricane Paul in 1981 by Bonillas, 1984). Extreme values up to 23,000 $\mathrm{m}^{3} \mathrm{~s}^{-1}$ were calculated for some individual sections in the same catchment (Table S-3). For the Cajoncito sections measured in deposits left by tropical storm Liza in 1976, our estimate is $\sim 3,000 \mathrm{~m}^{3} \mathrm{~s}^{-1}$ (Table S-3) a figure consistent with the hydrograph measurements by Bonillas (1984) on hurricane Paul in 1981.

Facies in the historical deposits generated by tropical cyclones -for example those deposited during tropical storm Liza (1976) in La Paz (Fig. 8, Table S-3) — are equivalent with those observed in Pleistocene - Holocene sediments in units Qt2 through Qt5, although a progressive reduction in magnitude of floods is evident from the diminished preservation of antidunes and transverse ribs in the younger Qt5 and Qt6 deposits (Table 1B). We deduce that deposition of all units occurred rapidly during intense or long duration tropical cyclones approaching or making landfall in the southern peninsula. Our record suggests therefore that variations in climate conditions during specific, discrete periods in the last $70 \mathrm{ky}$ allowed tropical storms to become both more intense and more frequent over the southern peninsula. These conditions waned during specific portions of the time period analyzed, and specifically, during the Holocene, driving finally the frequency and intensity of tropical cyclones to those similar to observed in the present day.

\subsection{Evolution of depositional events in the record}

The overall thickness of the sediment units diminishes from the Pleistocene (Qt2) throughout the Holocene (Qt5-6) fans (Figure 2; Table 1), similar to the evolution of the lower Colorado alluvial fans (Bull, 1991). Based on the observed bedforms (Table 1B) and compared to sediments of alluvial fans formed under conditions of rapid sedimentation and high discharges (cf. Duller et al., 2015), conditions prevailing during Qt2 through Qt4 were of larger sediment supply than Holocene to present-day conditions, along with active fan deposition. Thicknesses of tens of meters of sediment were deposited at locations in the middle and distal portions of the fans (Fig. 3D, 6A), contrasting with the reduced ( $<10 \mathrm{~m}$ in general) thickness on the Holocene units (Fig. 7). The lack of transverse gravel bars (transverse ribs) in units Qt5 and Qt6 (Table 1B) also suggests a progressive reduction in maximum energy flow events since the Late Pleistocene. Horizontal plane bedding and characteristic antidune bedforms are retained however 
in the sedimentology throughout the Holocene units, albeit with reduced wavelengths (compare Fig. 4 with Fig. 8). We conclude that the Holocene has witnessed potentially less and less intense arrival of cyclones than the late Pleistocene, although it did not lack completely arrivals, demonstrated by historical tropical storms Liza (1976) and Juliette (2001), among others (cf. Ragas et al., 2013; Villanueva, 2001; Antinao and Farfan, 2013).

\subsection{Self-channelization}

Self-channelization is evident in older units away from the outlet of major bedrock catchments. We hypothesize that as these surfaces get older, surface erosion results in the formation of a ridge-and-channel topography that eventually evolves into ballena topography. Temporal changes in surface topography are most likely related to soil profile development (e.g., silt and clay content increase) that tends to decrease surface infiltration and increase surface runoff, enhancing concentration of surface water into channels between interfluves. This process occurs however at a lesser scale in surfaces with low relief, like the younger Qt4 or Qt5. These surfaces are extensive enough in the landscape (Fig. 2) that occurrence of intense rainfall events might lead to surface flow, considering their high infiltration capacity. An example of surface flow in areas without obvious channels has been observed in historical storms like hurricane Liza (1976). During this storm, small channels formed on the surface of the Qt4-Qt5 fan, away (1 $\mathrm{km}$ ) from the main channel, and deposited sediment at distal positions in the fan without any upland bedrock catchment to source the water or the sediment. Reworked sediment might be eroded, transported and deposited in 0.5-1 m hollows, and landscape scars are rapidly healed with vegetation activity afterwards (cf. Antinao and Farfán, 2013, for similar observations on landslides). This effect might also partially explain some of the younger ages on the higher portion of Qt4 soil pit age profiles in San José (Fig. 6D, pit SJ2; also pit ST2, Table 2, and Table $\mathrm{S}-2$ ). In any case, the amount of sediment redeposited on distal sites during historic storms is small compared with the amount deposited in the main channels feeding sediment from upland catchments, and we consider the effects of self-channelization to be more relevant for the progressive toe erosion of fans, than for fan surface development (i.e., no subsidiary fans developing from fan medial sites).

\subsection{Cosmogenic ${ }^{10}$ Be depth profile results}


Cosmogenic ${ }^{10} \mathrm{Be}$ depth profiles indicate the age of the stabilization of the surface being analysed, giving also useful information regarding the isotope content inherited during previous transport and hillslope storage. Observed change in ${ }^{10} \mathrm{Be}$ concentration with depth was similar for both profiles, and deviations from an ideal exponential profile in EAO-2 can be explained by mixing in the upper layers of the profile by pedogenic processes not observed in the field. These mixing processes were nevertheless confirmed by other pit age sequences (cf. shallow Qt4 IRSL profiles in San José), and were restricted to the upper $50 \mathrm{~cm}$ of the pit. Sediment density analyses in the lab and the field yield density curves (Fig. 4B, F) that were used as input for the model, as cumulative densities. The density curve was consistent with expected pedogenic evolution from the parental material. For profile EAO-2, model runs including and excluding the upper two samples were performed in order to understand the effect of the mixing in the final model age. No improvement in uncertainty was found when running only the lower samples, and therefore it was decided to include all samples in the modeling effort. Consistency with one of the IRSL ages at 1-sigma, from a sample below the mixing zone, suggests that indeed the age of sedimentation and surface stabilization are very close.

The anomalously high ${ }^{10} \mathrm{Be}$ content of the second shallowest sample for EAO-3 is linked to an anomalously high density value that we associate with disruption of the horizon by subtle bioturbation at a deeper level in this older unit. Running the profile model without this sample data point does not improve obtained uncertainties. The remarkable agreement between the relatively deep IRSL sample and the profile age (Fig. 4) indicates stabilization occurring immediately after deposition of the event.

The soil profiles indicated minimal surface lowering based on the presence of a complete horizonation and pedogenic structures. The models showed in Figure 4 used as initial constraints, besides the indicated density profiles, maximum lowering amounts of $10 \mathrm{~cm}$ for each profile. Models returned however relatively flat distributions for erosion rates, with median values around $0 \mathrm{~cm} / \mathrm{ky}$. Model inheritance values are in the same order of magnitude for both profiles, with reduced uncertainties arising from the modeling of profiles with relatively deep $(>2 \mathrm{~m})$ samples.

\subsection{Chronology of events and evidence for discrete depositional periods.}


As discussed above, rapid deposition is suggested by the sequence of ages in specific sampled sections of Qt3 and Qt4, with cycles of rapid deposition recognized as distinct packages of alluvium. Inside each package, ages agree at 1-sigma (e.g., Fig. 6C, E; Fig. 7C). Additionally, although age estimates are in correct stratigraphic order for most of the dated samples, ages nevertheless overlap at 1-sigma for two consecutive sediment packages (SL-III section; Fig. 4). The chronology presented here in addition to that presented in Brown et al. (2014) allows us to be confident about the ranges of deposition for the alluvial sediments in the study area. Our interpretation is further supported by consistency of the chronology with that of Maloney (2009) in the Carrizal fault system, western La Paz basin (Fig. 1), using Optically Stimulated Luminescence (OSL) in quartz. Ages for their units Qya3 and Qya2 are consistent with our units Qt4 and Qt5o, at ranges of 13-7 ka and 6-1.3 ka. Soil data (this study) for the sites described in Maloney (2009) are consistent with development expected given the time range determined for surface stabilization of these units. Similarity of cosmogenic depth profile surface stabilization ages to luminescence burial ages both at a regional scale (Fig. 9) and at the pit scale (Fig. 5) indicate that sedimentation quickly stopped and was followed by a hiatus in deposition that allowed soils to form. Development of soils that are clearly distinguishable between mapped units (Table 1) at a regional scale and the well-defined chronology for Late Pleistocene units (Fig. 9) is indicative of discrete periods when deposition occurred.

These discrete periods that we interpret as dominated by deposition are not separated by sharp temporal boundaries from non-depositional periods. In a few cases ages in one unit overlap with ages on the older or younger unit (Fig. 9), because alluvial units were mapped according to a set of field criteria; besides the internal variability in age distribution in one unit, individual site hydrological and compositional factors might have played a role in masking relative age classification. We interpret periods when limited deposition is observed (e.g., around 20-30 and 40-50 ka) as having evolved like the Holocene, with reduced aggradation (in volume) that nevertheless is still observed when the age of individual sediment packages is considered. For sediments deposited during these periods, pedogenic and surface evolution from deposition to the present-day developed very similarly to younger or older larger sediment packages, and therefore we could not assign these sediments into distinct units, but instead decided to include them into the larger packages. 
Well-defined erosional boundaries separate each unit, from Qt2 to Qt6. These boundaries include current exposed surfaces for all units (e.g., Fig. 2C). No distinct buried soils have been identified within these sediment packages that would indicate a significant break in aggradation inside identified units Qt2 to Qt6, which instead show tens of single depositional packages about 1-3 $\mathrm{m}$ in thickness separated by depositional or light cross-cutting relations. These individual packages might be separated by a variable time gap that can range between decades to a few millennia at most (Fig. 4). In the latter case, oxidised sandy layers can be identified as stratigraphic markers (Fig. 6A). In the former case, and throughout all units, a change in sedimentation conditions is the only indication of a separation between events, for example grain-size changes or cross-cutting relations (Fig. 4, 8). The perceived intra-unit periodicity of sedimentation mentioned above is based mostly in the lack of soil development and it is similar with e.g., the periodicity interpreted for tropical cyclone-induced landsliding events, documented for San José basin in Antinao and Farfán (2013).

\section{A dynamic link to explain alluvial aggradation: implications for paleoclimate \\ 6.1. Tropical Pacific forcing of alluvial cycles}

The most important feature of the fan chronology (Fig. 9) is the cyclicity of deposition of the thicker units $(\mathrm{Qt} 2,3,4)$ that is correlative with the variation in summer insolation in an area of the tropical Pacific where eastern Pacific tropical cyclones are generated (Fig. 9E). This insolation variability is in turn, mostly controlled by precessional cycles (Berger, 1991). As far as we know this is the first record that documents a precession-driven alluvial chronology for southwestern North America. We propose that at these specific periods generation of more and more intense tropical cyclones in the eastern Pacific basin was accomplished by a larger amount of solar radiation received by the area of genesis of eastern Pacific tropical cyclones (i.e, between 10-20 N, Fig. 9E), accompanied by a weakening of the North Pacific High, hence reducing the intensity of the California Current (cf. Roberts, 2004; Lyle et al., 2010) and allowing the penetration of tropical waters, which has been documented at least for Qt4 times (17-11 ka) for the region offshore Baja California (Rodriguez-Sanz et al., 2013). The proposed mechanism has two competing features, as a northward movement of the Intertropical Convergence Zone (ITCZ) drives a larger pool of moisture closer to southwestern North America, but also a strengthening of the North Pacific High (NPH) that blocks advection of 
tropical moisture into the continent. Effects of this proposed mechanism should be more important mostly in the rising limb of the precessionaly-controlled insolation curve, as we observe in the southern Baja California record (Fig. 9F). Once the insolation maximum is reached, the NPH is at its maximum strength and conditions for transport of tropical moisture are reduced, not only for summer storms but also for winter extratropical cyclones.

The precessional cyclicity of the fan aggradation and associated correlation with high summer insolation is in contrast with previous studies of alluvial fan deposition in the region, interpreted primarily occurring in response to glacial-interglacial cycles. In these southwestern North America studies, fan aggradation is interpreted to occur in response to either a southward shift of westerlies winter storm band in response to disturbances caused to hemispheric circulation patterns by the development of the high latitude ice sheets (cf. Spelz et al., 2008; Armstrong et al., 2010; Owen et al., 2014), or as a result of enhanced activity of monsoonal thunderstorms under an overall climate shift from wetter to dryer conditions during deglaciation (e.g., Bull, 1991; Miller et al., 2010).

The three major aggradation units in the alluvial record described in this study (Qt2 to Qt4) indeed correlate with periods of alluvial fan formation in both the Peninsular Ranges and the Transverse Ranges in southern California and the northern Baja California peninsula (Fig. 9C; cf. Armstrong et al., 2010; Spelz et al., 2008; van der Woerd et al., 2013; McGill et al., 2013; Blisniuk et al., 2012; Owen et al., 2014). A recent compilation of records by Owen et al. (2014) also contains aggradation peaks at $\sim 35 \mathrm{ka}$ and $\sim 65 \mathrm{ka}$. These mostly southern California records are consistent with deposition during Qt2, Qt3 and Qt4, but also suggest that there is a LGM component that is not observed in Baja California, which is reasonable, because we interpret that sedimentation was triggered in Baja California by low latitude forcing that induced enhanced tropical storm precipitation. Periods of aggradation in Baja California also correlate with periods of increased runoff in a record from a high elevation southern California lake at $\sim 36 \mathrm{ka}$ and $\sim 53$ ka (Kirby et al., 2006; Fig. 9B), and similar records in lake systems across southwestern North America (e.g., Laguna San Felipe, 13-9 ka, Lozano-Garcia et al., 2002, Roy et al., 2012; Lago Santiaguillo, Durango, at 12.3-9.3 ka, Roy et al., 2014; Babicora, at 29-38 ka and 57-65 ka, Metcalfe et al., 2002; Fig. 9B). Similar to the alluvial record mentioned above, we note that the current interpretation of these lacustrine records is described as increased precipitation from disparate sources, e.g., due to an enhancement of the North American Monsoon (e.g., Metcalfe et 
al., 2002), or to south displacement of the westerlies (e.g., Roy et al., 2014) at different periods. Lyle et al. (2010, 2012) have suggested that an increase in direct transport of tropical Pacific moisture has been involved in hydrological changes for some of these lakes. The Baja California alluvial record is consistent with this idea, in that alluvial fan data neither records westerlies or monsoonal influences but instead direct tropical Pacific influence during the summer.

Consequently, our results provide an end-member perspective on a relatively unknown variable in southwestern North America hydroclimate variability: eastern Pacific tropical cyclones. The above discussed evidence for contemporaneous increase in effective moisture and runoff across this subtropical region where several hydroclimates dominate is consistent with our record. This temporal correlation suggests that a similar tropical forcing may play a role in the evolution of these northern records and that in future analyses the incorporation into the discussion of the tropical cyclone end-member is warranted in order to provide a more reliable assessment of the hydroclimates of the region during the late Pleistocene.

We compared also our alluvial record to two records of terrigenous supply to the offshore areas of southern California (ODP site 893; Fig. 1; Robert, 2004) and from the eastern Pacific, off southwestern Baja California (core MD02-2508; Fig. 1; Blanchet et al., 2007). In the southern California core, clay mineral assemblages indicating terrigenous supply were described as modulated by summer insolation, with peaks at $\sim 35 \mathrm{ka}$ and $\sim 60 \mathrm{ka}$ (Robert, 2004; Fig. 9A). The record of Robert (2004) also displays several maxima around the LGM and the late Pleistocene - Holocene transition. In core MD02-2508, minima in the hard isothermal remnant magnetization record (HIRM; Fig. 9D) can be used as a proxy for wet periods with increased terrigenous supply, as opposed to high peaks in the record when wind-blown magnetic minerals were brought into the core region under relative arid conditions and an enhanced anticyclone regime. Wet periods appear around $10 \mathrm{ka}$ and $\sim 30-35 \mathrm{ka}$ (Fig. 9D), coincident with our alluvial record for Qt3 and Qt4. Beyond 38 ka the HIRM record is only pinned by the Blake magnetic excursion at $\sim 120 \mathrm{ka}$ (Blanchet et al., 2007), which complicates any correlation with the already wide range of ages for Qt2 deposition. The striking relationship that must be highlighted is the apparent control of the alluvial record by insolation variation in the area and season most prone to genesis of tropical cyclones (Fig. 9E, F. This result emphasizes the potential for our record to be used as a strong benchmark for discrimination of tropical influence on any other alluvial record in southwestern North America. 


\subsection{Modulation by ENSO}

The alluvial record described in this study shows a period of enhanced sedimentation around 16-9 ka (Qt4 deposition, Fig. 9F). During this period, midden records for north and central Baja California show displacement of chaparral associations to their southernmost recorded position suggesting an increase of winter precipitation and a more equable, less seasonal climate (Van Devender, 1997; Rhode, 2002), consistent with increased water levels in present-day dry peninsular Lakes Chapala and Laguna San Felipe (Davis, 2003; Lozano-Garcia et al., 2002). Coexistence of increased winter precipitation along Baja California during the late Pleistocene-Holocene transition with more frequent arrival of large tropical storms is consistent with more frequent El Niño-like conditions during at least the early portion of this period (e.g., Koutavas et al., 2002, Masters, 2006; Grelaud et al., 2009), because it might have shifted winter storm tracks south as it does in the present day (e.g., Cayan et al., 1999). Although observations in marine cores in the Gulf of California, and along the eastern Pacific including offshore Baja California all support El Niño-like conditions during the late Pleistocene-Holocene transition (e.g., Koutavas and Joanides, 2012; Staines-Urias et al., 2015), the lack of proxies documenting unequivocally ENSO variability beyond that period precludes a more definite test of an hypothetical connection between ENSO and advection of tropical moisture into southwestern North America for the late Pleistocene. A precession-driven, coupled model describing sea surface temperature anomalies in the equatorial Pacific, extending back into MIS 5 is only partially consistent with the marine records described above for the late Pleistocene-Holocene (Clement et al., 1999; Fig. 9G), and with the alluvial record described here, that appears to be dominant only during the waning limbs of the NINO3 anomaly curve after maxima periods, even extending to periods of minima (Qt3).

Present-day observations of the effects of ENSO on synoptic patterns in southwestern North America however support a causative linkage between El Niño-like conditions and a larger role of tropical storms in hydroclimatology of the region. The warm phase of the El Niño Southern Oscillation negatively affects North American Monsoon activity (e.g., Castro et al., 2001; Gochis et al., 2007; Gochis and Berberry, 2011) At the same time, El Niño-like conditions could have increased tropical cyclone activity in terms of intense (Category 4-5) hurricane occurrence, similar to what has been documented during the last 50 years in the Eastern Pacific 
Basin (e.g., Gray and Sheaffer, 1991; Elsner and Kara, 1999; Chu, 2004; Romero-Vadillo et al., 2007; Raga et al., 2013). Although a few studies have found no influence from El Niño on the total amount of cyclones (Cayan and Webb, 1992; Raga et al., 2013), there is a growing body of literature that has actually found evidence for a positive effect of ENSO-warm phase on occurrence of tropical storms (Rodgers et al., 2000; Jauregui, 2003; Jien et al., 2015).

As mentioned above, a northern, possibly wider, ITCZ at times of increased summer insolation in the Northern Hemisphere (Haug et al., 2001; Koutavas and Lynch-Stieglitz, 2005; Broccoli et al., 2006), would provide a larger amount of moisture to tropical cyclones, which were also more likely to recurve northward and eastward given both the weakening of the Horth Pacific High and the increase in cut-off lows both expected for El Niño or warm ENSO conditions in the Eastern Pacific (Cayan and Webb, 1992).

It is important to note that all the above mentioned causal mechanisms are interconnected and none should be flagged as a standalone cause for the proposed increase in advection of tropical moisture into the coast of southwestern America. Warm ENSO conditions, although important for generation and advection of tropical storms, are not sufficient to develop a pattern of alluvial deposition by itself. The clustering of dates, which mostly appear between a NINO3 model maxima and an insolation maxima (Fig. 9) is interpreted as reflecting a sequence of effects occurring during several thousands of years. First, an El Niño-like state in the tropical Pacific benefits formation and arrival of strong storms directly, as stated above; second, as that effect wanes, the insolation effect takes over and maintains the cycle of tropical moisture advection active. Note that a reduction of activity around the LGM also can be attributed to the still lingering effects of hemispheric cooling at a time when the continental icecaps were at their maximum extension. Although the model NINO3 anomaly was rising during the termination, the ITCZ was still closer to its southernmost position during the late Pleistocene (cf. Broccoli et al., 2006), making the source of moisture too distant to be advected to North America either in winter into the westerly flow by an enlarged Aleutian Low (cf. Santa Barbara Basin data by Grelaud et al., 2009), or in summer, when initiation of tropical cyclone circulation would be affected negatively by the reduced Coriolis force as the region of atmospheric instability lies closer to the Equator.

\subsection{Implications on hydroclimate analysis of southwestern North America}


Our results indicate that tropical cyclones constitute a relevant player along with winter extratropical cyclones and the NAM in late Pleistocene hydroclimatology of the southwestern continent. The arrival of tropical moisture is therefore not only tied to sourcing flooding events that help maintain high lake levels, as suggested by Lyle et al. (2012), but also to major sediment transport events affecting both the arid and semiarid catchments of the region and the lowlands. In our study, direct summer high intensity, relatively long-lived, and widespread storms affected the southern Baja California region, and could spread north as far as $25 \mathrm{~N}$ and beyond given ocean conditions recorded at that latitude for at least the late Pleistocene-Holocene transition (cf. Lyle et al., 2010; Rodriguez-Sanz et al., 2013). More research is warranted, especially focusing in the areas north of our study sites in southern California that show similar timing to our record, as discussed above, but that have been interpreted as derived from other synoptic patterns. In addressing this problem, detailed attention must be put into describing and interpreting the sedimentology of the deposits, as it has proven critical in our research to understand storm conditions that generate the alluvial deposits.

A direct outcome for future research will be the improved understanding of climate conditions and landscape variables governing the arrival of powerful tropical storms to the continent. This in turn will help all involved scientific and broader communities to better assess and prepare for current and future unique related hazards. A recent analysis has shown for example that the largest variability in summer precipitation during the $20^{\text {th }}$ century in southern California is explained by tropical cyclone events (Fierro, 2014), not by ENSO or any other forcing. This observation, coupled with predicted trends of intensification of tropical cyclones worldwide for the $21^{\text {st }}$ century (e.g., Emanuel, 2013), and to the results presented here, should make the case to fully incorporate tropical cyclones into an integrated hazards approach for the southwestern continent.

\section{Conclusion}

The alluvial sequence developed in southern Baja California represents regional, discrete periods during the late Pleistocene and early Holocene when climatic conditions allowed more and more intense tropical cyclone events to approach the peninsula generating large fluvial discharges and pronounced aggradation of the alluvial fans. The linkage between tropical cyclone precipitation and alluvial aggradation is supported by analysis of the sedimentology of 
historical alluvial terraces which were deposited by large tropical cyclone events.

Sedimentological features linked to this deposition include horizontal planar bedding and the generation and preservation of antidune bedforms, and coincide with features observed in older units. Some geological features nevertheless are unique (i.e., transverse ribs, longer wavelength antidunes) and reveal the extraordinary power of the storms that generated them.

A period of regional aggradation began near $\sim 70 \mathrm{ka}$ with the deposition of unit Qt2, culminating at $10 \mathrm{ka}$, with deposition of the alluvial unit Qt4 (Fig. 9). The thickest alluvial deposits correspond to those of unit Qt2, followed by Qt3 and Qt4. A second, incisional phase developed as regional incision of older units increased after deposition of unit Qt4, leading to the progressive development of a channelized alluvial landscape and deposition of units Qt5 and Qt6 on it. Sedimentary packages in all units are composed of multiple 1-3 $\mathrm{m}$ thick alluvial packages representing individual storms that deposited sediments in upper-flow stage beds. Aggradational units (Qt2-Qt4) covered broad (>2 km) channels in the form of sheetflood deposition while incisional stage deposits are mostly confined to channels of $\sim 0.5-2 \mathrm{~km}$ width. Continuous deposition of the thicker sequences at timescales of centuries to millennia is demonstrated by closely spaced dates in vertical profiles. Disconformities between major units are evident, indicated by partly eroded buried soils, and supporting the existence of discrete periods of deposition.

The discrete depositional periods indicated by the chronological and stratigraphic relations can be associated with specific periods when summer (JJAS) insolation in the eastern Pacific at 10-20 N recorded maxima determined by precessional cycles. Modulation of this pattern by El Niño-like conditions in the tropical Pacific is apparent, especially during the late Pleistocene-Holocene transition, although more research is warranted to extend the range of proxies that can be linked to this pattern into the Pleistocene.

A precession-controlled alluvial record for southern Baja California can be used as a benchmark to discriminate tropically driven deposition in more complex alluvial records elsewhere in southwestern North America. The late Pleistocene depositional series is mainly comprised of three precession-cycled events (Fig. 9) followed by a reduction in size of units during the Holocene. By comparing the chronology and sedimentology of the Baja California alluvial fans to records in the Mojave and Sonoran deserts or along southern California (cf. 
Owen et al., 2014), it should be possible to start differentiating between climate components, even if winter-storm chronology partially overlaps with the tropically-driven series.

\section{Acknowledgements}

We thank two anonymous reviewers for their helpful comments on an earlier version of our manuscript. U.S. National Science Foundation NSF EAR 1123481 grant to J.L.A., E.M., and E.R. and US Army Research Office Contract No. DAAD19-03-1-0159 to E.M. supported this research. J.L.A. was also funded by postdoctoral support funds from the Division of Earth and Ecosystem Sciences (DEES) of the Desert Research Institute (DRI) and by the National Research Center for Integrated Natural Disaster Management (Chile). L. Farfán and S. Mayer (CICESE, Unidad La Paz) provided partial logistical support for field activities. Discussions with G. Martinez (UABCS), K.-b. Liu (LSU), and A. Hidy (LLNL) improved the manuscript. S. Baker (DRI) helped with figure design. G. Yang (Dalhousie) and E. Huenupi (DRI) performed all analytical work for cosmogenic isotope extraction. This manuscript is contribution LLNLJRNL-676762.

\section{References}

Allen, J.R.L., 1982. Sedimentary Structures: Their Character and Physical Basis. Developments in Sedimentology, 30 (parts I and II). Amsterdam, Elsevier. 593 p.

Antinao, J.L., Farfán, L.M., 2013. Occurrence of landslides during the approach of tropical cyclone Juliette (2001) into Baja California Sur, Mexico. Atmosfera 26 (2), 183-208.

Antinao, J.L., McDonald, E., 2011. Three Hundred Years of Hurricanes in Baja California from Documentary Sources: Implications for Sediment Flux and Landscape Evolution in the Peninsula. Annual Conference, 56, American Association of Geographers, Seattle.

Armstrong, P., Perez, R., Owen, L.A., Finkel, R.C., 2010. Timing and controls on late Quaternary landscape development along the eastern Sierra el Mayor, northern Baja California, Mexico. Geomorphology 114 (3), 415-430.

Berger, A., Loutre, M., 1991. Insolation values for the climate of the last 10 million years. Quaternary Science Reviews 10 (4), 297-317.

Blanchet, C.L., Thouveny, N., Vidal, L., Leduc, G., Tachikawa, K., Bard, E., Beaufort, L., 2007. Terrigenous input response to glacial/interglacial climatic variations over southern Baja California: a rock magnetic approach. Quaternary Science Reviews 26 (25-28), 3118-3133. 
Blisniuk, K., Oskin, M., Fletcher, K., Rockwell, T., Sharp, W., 2012. Assessing the reliability of U-series and ${ }^{10}$ Be dating techniques on alluvial fans in the Anza Borrego Desert, California. Quaternary Geochronology 13 (0), 26-41.

Bonillas, E., 1984. Análisis Hidrológico de la zona sur del estado de Baja California Sur. BSc Thesis, U. Sonora, Mexico. 126 p.

Brocard, G., van der Beek, D., Bourlès, D., Siame, L., Mugnier, J.-, 2003. Long-term fluvial incision rates and postglacial river relaxation time in the French Western Alps from ${ }^{10} \mathrm{Be}$ dating of alluvial terraces with assessment of inheritance, soil development and wind ablation effects. Earth and Planetary Science Letters 209, 197-214.

Broccoli, A.J., Dahl, K.A., Stouffer, R.J., 2006. Response of the ITCZ to Northern Hemisphere cooling. Geophysical Research Letters 33 (1).

Brown, N.D., Rhodes, E.J., Antinao, J.L., McDonald, E.V., 2014. Single-grain post-IR IRSL signals from Kfeldspars from alluvial fan deposits in Baja California Sur, Mexico. Quaternary International 362: 132-138. doi:10.1016/j.quaint.2014.10.024.

Bull, W.B., 1991. Geomorphic responses to climatic change. Oxford University Press, Oxford.

Busch, M.M., Arrowsmith, J.R., Umhoefer, P.J., Coyan, J.A., Maloney, S.J., Gutiérrez, G.M., 2011. Geometry and evolution of rift-margin, normal-fault-bounded basins from gravity and geology, La Paz-Los Cabos region, Baja California Sur, Mexico. Lithosphere 3 (2), 110-127.

Castro, C.L., McKee, T.B., Pielke Sr., R.A., 2001. The relationship of the North American Monsoon to Tropical and North Pacific Sea Surface Temperatures as revealed by observational analyses. Journal of Climate 14, 4449-4473.

Castro, C.L., McKee, T.B., Pielke, R.A., 2001. The Relationship of the North American Monsoon to Tropical and North Pacific Sea Surface Temperatures as Revealed by Observational Analyses. Journal of Climate 14 (24), 4449-4473.

Cayan, D., Webb, R., 1992. El Niño/Southern Oscillation and streamflow in the western United States. In: Díaz, H.F., Markgraf, V. (Eds.), El Niño: Historical and paleoclimate aspects of the Southern Oscillation. Cambridge University Press, Cambridge, pp. 29-68.

Chu, P., 2004. ENSO and Tropical Cyclone Activity. In: Murnane, R.J., Liu, K. (Eds.), Hurricanes and Typhoons: Past, Present, and Future. Columbia University Press, pp. 297-332.

Clapp, E.M., Bierman, P.R., Nichols, K.K., Pavich, M., Caffee, M., 2001. Rates of sediment supply to arroyos from upland erosion determined using in situ-produced cosmogenic 10Be and 26Al. Quaternary Research 55, 235-245.

Clark, P.U., Dyke, A.S., Shakun, J.D., Carlson, A.E., Clark, J., Wohlfarth, B., Mitrovica, J.X., Hostetler, S.W., McCabe, 2009. The Last Glacial Maximum. Science 325, 710-714.

Clement, A.C., Seager, R., Cane, M.A., 1999. Orbital controls on the El Nino/Southern Oscillation and the tropical climate. Paleoceanography 14 (4), 441-456. 
Davis, L., 2003. Geoarchaeology and geochronology of pluvial Lake Chapala, Baja California, Mexico. Geoarcheology 18 (2), 205-223.

De Boer, B., Van de Wal, R.S.W., Lourens, L. J., Bintanja, R., Reerink, T. J., 2012. A continuous simulation of global ice volume over the past 1 million years with 3-D ice-sheet models. Climate Dynamics, 2012, doi: 10.1007/s00382-012-1562-2.

Del Monte-Luna, P., Arreguín-Sánchez, F., Godínez-Orta , L., López-Ferreira , C.A., 2005. Batimetría actualizada de la Bahía de La Paz, Baja California Sur, México. Oceánides 20 (1-2), 75-77.

Díaz, S.C., Salinas-Zavala, C.A., Hernández-Vázquez, S., 2008. Variability of rainfall from tropical cyclones in northwestern Mexico and its relation to SOI and PDO. Atmósfera 21 (2), 213-223.

Driscoll, R. S., Merkel, D.L., Radloff, D. L., Snyder, D.E., Hagihara, J.S., 1984. An ecological land classification framework for the United States. U.S. Department of Agriculture, Miscellaneous Publication 1439, Washington, DC, $56 \mathrm{pp}$.

Duller, R., Warner, N.H., De Angelis, S., Armitage, J.J., Poyatos-More, M., 2015. Reconstructing the timescale of a catastrophic fan-forming event on Earth using a Mars model. Geophysical Research Letters. 42, 10,32410,332, doi:10.1002/2015GL066031.

Emanuel, K.A., 2013. Downscaling CMIP5 climate models shows increased tropical cyclone activity over the 21st century, Proceedings of the National Academy of Sciences 110 (30),: 12219-12224.

Englehart, P.J., Douglas, A.V., 2001. The role of eastern North Pacific tropical storms in the rainfall climatology of western Mexico. International Journal of Climatology 21 (11), 1357-1370.

Etheredge, D., Gutzler, D.S., Pazzaglia, F.J., 2004. Geomorphic response to seasonal variations in rainfall in the Southwest United States. Geological Society of America Bulletin 116, 606-618.

Farfán, L. M., 2004. Regional Observations during the Landfall of Tropical Cyclone Juliette (2001) in Baja California, Mexico. Monthly Weather Review. 132, 1575-1589.

Farfán, L.M., Fogel, I., 2007. Influence of tropical cyclones on humidity patterns over southern Baja California, Mexico. Monthly Weather Review, 135, 1208-1214.

Fierro, A. O., 2014. Relationships between California rainfall variability and large-scale climate drivers. International Journal of Climatology 34, 3626-3640. doi:10.1002/joc.4112.

Fierstine, H.L., Applegate, S.P., González-Barba, G., Schwennicke, T., Espinosa-Arrubarrena, L., 2001. A fossil blue marlin (Makaira nigricans Lacépéde) from the Middle Facies of the Trinidad Formation (Upper Miocene to Upper Pliocene), San José del Cabo Basin, Baja California Sur, México. Bulletin of the Southern California Academy of Sciences 100, 59-73.

Fletcher, J.M., Mungui, L., 2000. Active continental rifting in southern Baja California, Mexico: Implications for plate motion partitioning and the transition to seafloor spreading in the Gulf of California. Tectonics 19 (6), 1107-1123.

Foley, M.G., 1977. Gravel-lens formation in antidune regime flow-a quantitative hydrodynamic indicator. Journal of Sedimentary Petrology 47(2), 738-746. 
Forbis, T.D., Douglas, R., Gorsline, D., Nava-Sanchez, E., Mack, L., Banner, J., 2004. Late Pleistocene (Last Interglacial) terrace deposits, Bahia Coyote, Baja California Sur, Mexico. Quaternary International 120 (1), 29-40.

Frankel, K.L., Brantley, K.S., Dolan, J.F., Finkel, R.C., Klinger, R.E., Knott, J.R., Machette, M.N., Owen, L.A., Phillips, F.M., Slate, J.L., 2007. Cosmogenic 10Be and 36Cl geochronology of offset alluvial fans along the northern Death Valley fault zone; implications for transient strain in the eastern California shear zone. Journal of Geophysical Research 112, B06407.

Frankel, K.L., Brantley, K.S., Dolan, J.F., Finkel, R.C., Klinger, R.E., Knott, J.R., Machette, M.N., Owen, L.A., Phillips, F.M., Slate, J.L., 2007. Cosmogenic 10Be and 36Cl geochronology of offset alluvial fans along the northern Death Valley fault zone; implications for transient strain in the eastern California shear zone. Journal of Geophysical Research 112, B06407.

Gochis, D.J., Berberry, E.H., 2011. Contributions from the North American Monsoon Experiment towards improved understanding and prediction of high impact weather and climate events. In: Chang, C., Ding, Y., Lau, N., Johnson, R.H., Wang, B., Yasunari, T. (Eds.), The Global Monsoon System. World Scientific, Singapore, pp. 159-180.

Gochis, D.J., Brito-Castillo, L., James Shuttleworth, W., 2007. Correlations between sea-surface temperatures and warm season streamflow in northwest Mexico. International Journal of Climatology 27 (7), 883-901.

Gosse, J.C., Phillips, F.M., 2001. Terrestrial in situ cosmogenic nuclides; theory and application. Quaternary Science Reviews 20 (14), 1475-1560.

Gray, W.M., Sheaffer, J.D., 1991. El Niño and QBO influences on tropical cyclone activity. In: Glantz, M.H., Katz, R.W., Nicholls, N. (Eds.), Teleconnections linking worldwide anomalies. Cambridge University Press, Cambridge, pp. 257-284.

Grelaud, M., Beaufort, L., Cuven, S., Buchet, N., 2009. Glacial to interglacial primary production and El NiñoSouthern Oscillation dynamics inferred from coccolithophores of the Santa Barbara Basin. Paleoceanography 24, PA1203.

Gutzler, D., 2004. An index of interannual precipitation variability in the core of the North American monsoon region. Journal of Climate 17 (22), 4473-4480.

Haug, G.H., Hughen, K.A., Sigman, D.M., Peterson, L.C., Rohl, U., 2001. Southward Migration of the Intertropical Convergence Zone Through the Holocene. Science 293 (5533), 1304-1308.

Hidy, A., Gosse, J.C., Blum, M.D., Gibling, M.R., 2014. Glacial-interglacial variation in denudation rates from interior Texas, USA, established with cosmogenic nuclides. Earth and Planetary Science Letters 390, 209. 221. http://dx.doi.org/10.1016/j.eps1.2014.01.011.

Hidy, A.J., Gosse, J.C., Pederson, J.L., Mattern, J.P., Finkel, R.C., 2010. A geologically constrained Monte Carlo approach to modeling exposure ages from profiles of cosmogenic nuclides: An example from Lees Ferry, Arizona. Geochemistry, Geophysics, Geosystems 11, Q0AA10.

Hua, Q., Barbetti, M., Rakowski, A., 2013. Atmospheric Radiocarbon for the Period 1950-2010. Radiocarbon, 55(4), 2059-2072. doi:10.2458/azu_js_rc.55.16177. 
Huckleberry, G., 1996. Historical Geomorphology of the Gila River. Arizona Geological Survey Open-File Report 96-14, $31 \mathrm{pp}$.

Huntley, D.J., Lamothe, M., 2001. Ubiquity of anomalous fading in Kfeldspars and the measurement and correct. Canadian Journal of Earth Sciences 38, 1093-1106.

Jáuregui, E., 2003. Climatology of landfalling hurricanes and tropical storms in Mexico. Atmósfera 16, 193-204.

Jien, J.Y., Gough, W.A., Butler, K., 2015. The influence of El Niño-Southern Oscillation on tropical cyclone activity in the Eastern North Pacific Basin. Journal of Climate 28, 2459-2474.

Kennedy, J. F., 1961, Stationary waves and antidunes in alluvial channels: Report No. KH-R-2, W. M. Keck Laboratory of Hydraulics and Water Resources, California Institute of Technology, Pasadena, Calif., 146 p.

Kennedy, J.F., 1969. The formation of sediment ripples, dunes and antidunes. Annual Reviews of fluid Mechanics, $1,147-168$.

Kent, E.J., 2011. Towards defining the extent of climatic influence on alluvial fan sedimentation in semi-arid Sonoran and Mojave Deserts, southern California, USA and Baja California, northern Mexico. MSc Thesis, U. Cincinatti, Ohio, 53 p.

Kirby, M.E., Feakins, S.J., Bonuso, N., Fantozzi, J.M., Hiner, C.A., 2013. Latest Pleistocene to Holocene hydroclimates from Lake Elsinore, California. Quaternary Science Reviews 76 (0), 1-15.

Kirby, M.E., Lund, S.P., Bird, B.W., 2006. Mid-Wisconsin sediment record from Baldwin Lake reveals hemispheric climate dynamics (Southern CA, USA). Palaeogeography, Palaeoclimatology, Palaeoecology 241 (2), 267283.

Kirby, M.E., Zimmerman, S.R.H., Patterson, W.P., Rivera, J.J., 2012. A 9170-year record of decadal-to-multicentennial scale pluvial episodes from the coastal Southwest United States: a role for atmospheric rivers? Quaternary Science Reviews 46 (0), 57-65.

Koutavas, A., Joanides, S., 2012, El Niño-Southern Oscillation extrema in the Holocene and Last Glacial Maximum, Paleoceanography, 27, PA4208, doi:10.1029/2012PA002378.

Koutavas, A., Lynch-Stieglitz, J., 2005. Variability of the Marine ITCZ over the eastern Pacific during the past 30,000 years. In: Diaz, H.F., Bradley, R.S. (Eds.), The Hadley Circulation: Present, Past and Future. Kluwer Academic Publishers, Dordrecht, pp. 347-369.

Koutavas, A., Lynch-Stieglitz, J., Marchitto Jr., T.M., Sachs, J.P., 2002. El Niño-Like Pattern in Ice Age Tropical Pacific Sea Surface Temperature. Science 297 (5579), 226-230.

Leckie, D.A., 1994. Canterbury Plains, New Zealand - implications for sequence stratigraphic models, American Association of Petroleum Geologists Bulletin 78, 1240-1256.

Li, H.-., Xu, X.-., Ku, T.-., You, C.-., Buchheim, H.P., Peters, R., 2008. Isotopic and geochemical evidence of palaeoclimate changes in Salton Basin, California, during the past $20 \mathrm{kyr}$ : $1 . \delta 18 \mathrm{O}$ and $\delta 13 \mathrm{C}$ records in lake tufa deposits. Palaeogeography Palaeoclimatology Palaeoecology 259 (2-3), 182-197.

Lozano-García, M.S., Ortega Guerrero, B., Sosa-Najera, S., 2002. Mid- to Late-Wisconsin Pollen Record of San Felipe Basin, Baja California. Quaternary Research 58 (1), 84-92. 
Lyle, M., Heusser, L., Ravelo, C., Andreasen, D., Olivarez Lyle, A., Diffenbaugh, N., 2010, Pleistocene water cycle and eastern boundary current processes along the California continental margin, Paleoceanography, 25, PA4211, doi:10.1029/2009PA001836.

Lyle, M., Heusser, L., Ravelo, C., Yamamoto, M., Barron, J.A., Diffenbaugh, N.S., Herbert, T., Andreasen, D., 2012. Out of the Tropics: The Pacific, Great Basin Lakes, and Late Pleistocene Water Cycle in the Western United States. Science 337, 1629-1633. doi: 10.1126/science.1218390.

Mahan, S.A., Miller, D.M., Menges, C.M., Yount, J.C., 2007. Late Quaternary stratigraphy and luminescence geochronology of the northeastern Mojave Desert. Quaternary International 166 (1), 61-78.

Maloney, S.J., 2009. Late Quaternary Faulting History of the Northern El Carrizal Fault, Baja California Sur, Mexico. Master or Science, Geology Thesis, Northern Arizona University, Flagstaff, 196 pp.

Martinez Gutierrez, G., Mayer, L., 2004. Huracanes en Baja California, México, y sus implicaciones en la sedimentación en el Golfo de California. GEOS 24(1), 57-64.

Martínez-Gutiérrez, G., Sethi, P.S., 1997. Miocene-Pleistocene sediments within the San José del Cabo Basin, Baja California Sur, Mexico. Geological Society of America Special Papers 318, 141-166.

Masters, P., 2006. Holocene sand beaches of southern California: ENSO forcing and coastal processes on millennial scales. Palaeogeography, Palaeoclimatology, Palaeoecology 232 (1), 73-95.

Matmon, A., Schwartz, D.P., Finkel, R., Clemmens, S., Hanks, T., 2005. Dating offset fans along the Mojave section of the San Andreas fault using cosmogenic 26Al and 10Be. Geological Society of America Bulletin, 117, 5-6, 795-807.

McFadden, L.D., Ritter, J.B., Wells, S.G., 1989. Use of multiparameter relative-age methods for age estimation and correlation of alluvial fan surfaces on a desert piedmont, eastern Mojave Desert, California. Quaternary Research 32 (3), 276-290.

McGill, S.F., Owen, L.A., Weldon, R.J., Kendrick, K.J., 2013. Latest Pleistocene and Holocene slip rate for the San Bernardino strand of the San Andreas fault, Plunge Creek, Southern California: Implications for strain partitioning within the southern San Andreas fault system for the last 35 k.y. Geological Society of America Bulletin 125 (1-2), 48-72.

Metcalfe, S., Say, A., Black, S., McCulloch, R., O'Hara, S., 2002. Wet Conditions during the Last Glaciation in the Chihuahuan Desert, Alta Babicora Basin, Mexico. Quaternary Research 57 (1), 91-101.

Miall, A., 1996. The geology of fluvial deposits: sedimentary facies, basin analysis, and petroleum geology. Springer, Berlin.

Miall, A., 2000. Principles of sedimentary basin analysis. Springer, Berlin.

Miller, D.M., Schmidt, K.M., Mahan, S.A., McGeehin, J.P., Owen, L.A., Barron, J.A., Lehmkuhl, F., Lohrer, R., 2010. Holocene landscape response to seasonality of storms in the Mojave Desert. Quaternary International 215 (1-2), 45-61.

Ortega Guerrero, B., Caballero Miranda, M., Lozano García, S., De la O Villanueva, M., 1999. Palaeoenvironmental record of the last $70000 \mathrm{yr}$ in San Felipe Basin, Sonora desert, Mexico: preliminary results. Geofísica Internacional 38 (3), 1-11. 
Owen, L.A., Clemmens, S.J., Finkel, R.C., Gray, H., 2014. Late Quaternary alluvial fans at the eastern end of the San Bernardino Mountains, Southern California. Quaternary Science Reviews 87, 114-134.

Parker, J.T.C., 1995. Channel Change and Sediment Transport in Two Desert Streams in Central Arizona, 1991-92. U.S. Geological Survey Water-Resources Investigations Report 95-4059, 42 pp.

Raga, G.B., Bracamontes-Cevallos, B., Farfán, L.M., Romero-Centeno, R., 2013. Landfalling tropical cyclones on the Pacific coast of Mexico: 1850-2010. Atmósfera 26(2), 209-220.

Reimer, P., Bard, E., Bayliss, A., Beck, J., Blackwell, P., Bronk Ramsey, C., Buck, C., Cheng, H., Edwards, R., Friedrich, M., Grootes, P., Guilderson, T., Haflidason, H., Hajdas, I., Hatté, C., Heaton, T., Hoffmann, D., Hogg, A., Hughen, K., Kaiser, K., Kromer, B., Manning, S., Niu, M., Reimer, R., Richards, D., Scott, E., Southon, J., Staff, R., Turney, C., van der Plicht, J., 2013. IntCal13 and Marine13 Radiocarbon Age Calibration Curves 0-50,000 Years cal BP. Radiocarbon, 55(4), 1869-1887. doi:10.2458/azu_js_rc.55.16947.

Rhode, D., 2002. Early Holocene juniper woodland and chaparral taxa in the Central Baja California peninsula, Mexico. Quaternary Research 57 (1), 102-108.

Rhodes, E., 2011. Optically Stimulated Luminescence Dating of Sediments over the Past 200,000 Years. Annual Review of Earth and Planetary Sciences 39, 461-488.

Robert, C., 2004. Late Quaternary variability of precipitation in Southern California and climatic implications: clay mineral evidence from the Santa Barbara Basin, ODP Site 893. Quaternary Science Reviews 23 (9-10), 1029-1040.

Rodgers, E.B,; Adler, R.F., Pierce, H.F., 2000. Contribution of tropical cyclones to the North Pacific climatological rainfall as observed from satellites. Journal of Applied Meteorology 39, 1658-1678.

Rodríguez-Sanz, L., Mortyn, P. G. , Herguera, J. C. , Zahn, R., 2013. Hydrographic changes in the tropical and extratropical Pacific during the last deglaciation, Paleoceanography, 28, 529-538, doi:10.1002/palo.20049.

Roy, P.D., Caballero, M., Lozano, R., Ortega, B., Lozano, S., Pi, T., Israde, I., Morton, O., 2010. Geochemical record of Late Quaternary paleoclimate from lacustrine sediments of paleo-lake San Felipe, western Sonora Desert, Mexico. Journal of South American Earth Sciences 29 (3), 586-596.

Roy, P.D., Quiroz-Jiménez, J.D., Chávez-Lara, C.M., Sánchez-Zavala, J.L., Pérez-Cruz, L.L., Sankar, G.M., 2014. Humid Pleistocene-Holocene transition and early Holocene in sub-tropical northern Mexico and possible Gulf of California forcing. Boreas 43 (3), 577-587.

Roy, P.D., Quiroz-Jiménez, J.D., Pérez-Cruz, L.L., Lozano-García, S., Metcalfe, S.E., Lozano-Santacruz, R., LópezBalbiaux, N., Sánchez-Zavala, J.L., Romero, F.M., 2013. Late Quaternary paleohydrological conditions in the drylands of northern Mexico: a summer precipitation proxy record of the last 80 cal ka BP. Quaternary Science Reviews 78 (0), 342-354.

Sirkin, L., Pedrín-Avilés, S., Padilla-Arredondo, G., Díaz-Rivera, E., 1994. Holocene vegetation and climate of Baja California Sur, Mexico. Revista Mexicana de Ciencias Geológicas 11 (1), 79-86. 
Spelz, R.M., Fletcher, J.M., Owen, L.A., Caffee, M.W., 2008. Quaternary alluvial-fan development, climate and morphologic dating of fault scarps in Laguna Salada, Baja California, Mexico. Geomorphology 102 (3-4), 578-594.

Staines-Urias, F., González-Yajimovich. O., Beaufort, L., 2015. Reconstruction of past climate variability and ENSO-like fluctuations in the southern Gulf of California (Alfonso Basin) since the last glacial maximum, Quaternary Research 83(3), 488-501. http://dx.doi.org/10.1016/j.yqres.2015.03.007.

Summerfield, M.A., 1985. Plate tectonics and landscape development on the African continent. In: Morisawa, M., Hack, J., Editors, Tectonic Geomorphology, Allen and Unwin, Boston, pp. 27-51.

Szabo, B.J., Hausback, B.P., Smith, J.T., 1990. Relative inactivity during the last 140,000 years of a portion of the La Paz fault, southern Baja California Sur, Mexico. Environmental Geology and Water Sciences 15 (2), 119-122.

Umhoefer, P.J., Maloney, S.J., Buchanan, B., Arrowsmith, J.R., Martinez-Gutiérrez, G., Kent, G., Driscoll, N., Harding, A., Kaufman, D., Rittenour, T., 2014. Late Quaternary faulting history of the Carrizal and related faults, La Paz region, Baja California Sur, Mexico. Geosphere 10 (3), 476-504.

van der Woerd, J., Klinger, Y., Sieh, K., Tapponnier, P., Ryerson , F.J., Mériaux, A.-S., 2006. Long-term slip rate of the southern San Andreas fault from 10Be-26Al surface exposure dating of an offset alluvial fan. Journal of Geophysical Research 111 (B04407). doi:10.1029/2004JB003559.

Van Devender, T.R., 1997. 21,000 years of vegetation change in the northern Vizcaino, Baja California. Second Annual Baja California Botanical Symposium, August 14-16, 1997, San Diego, California.

Villanueva, E., 2001. Presencia de Huracanes en Baja California Sur. El caso del ciclón Liza. Maestro Historia Regional Thesis, Universidad Autónoma Baja California Sur, La Paz, Baja California Sur, Mexico, 279 pp.

Wagner, J.D.M., Cole, J.E., Beck, J.W., Patchett, P.J., Henderson, G.M., Barnett, H.R., 2010. Moisture variability in the southwestern United States linked to abrupt glacial climate change. Nature Geoscience 3 (2), 110-113.

Webb, R.H., Magirl, C.S., Griffiths, P.G., Boyer, D.E., 2008. Debris flows and floods in the southeastern Arizona from extreme precipitation in July 2006: Magnitude, frequency, and sediment delivery. U.S. Geological Survey Open File Report 2008-1274, 95 pp.

Wintle, A.G., Murray, A.S., 2006. A review of quartz optically stimulated luminescence characteristics and their relevance in single-aliquot regeneration dating protocols. Radiation Measurements 41, 369-391. 
Table 1. A. Summary of deposit thickness, surface morphology and soil morphology for the alluvial units.

\begin{tabular}{|c|c|c|c|c|c|c|c|c|c|c|}
\hline Unit & $\begin{array}{c}\text { Observed } \\
\text { thickness } \\
(\mathrm{m})\end{array}$ & $\begin{array}{c}\text { Surface } \\
\text { Morphology }\end{array}$ & $\begin{array}{c}\text { Number } \\
\text { of soil } \\
\text { profiles }\end{array}$ & $\begin{array}{c}\text { Soil } \\
\text { Depth }^{1} \\
\text { (cm) }\end{array}$ & $\begin{array}{c}\text { B } \\
\text { Thickness } \\
(\mathrm{cm})\end{array}$ & $\begin{array}{c}\text { B } \\
\text { horizon } \\
\text { Hue }^{3} \\
\end{array}$ & $\begin{array}{c}\text { B } \\
\text { Horizon }^{\text {Type }}{ }^{4} \\
\end{array}$ & $\begin{array}{c}\text { Best Soil } \\
\text { Structure }^{5}\end{array}$ & $\begin{array}{c}\text { Dry } \\
\text { Consistence }^{6}\end{array}$ & $\begin{array}{c}\text { Finest } \\
\text { Soil } \\
\text { Texture }\end{array}$ \\
\hline Qt6 & $2-3$ & Bar/swale & 1 & 4 & 0 & $10 \mathrm{YR}$ & none & pl-sg & lo-so & $\mathrm{S}$ \\
\hline Qt5y & $2-3$ & Bar/swale & 4 & $43-57$ & $29-42$ & 10YR & weak Bw & sg-sbk & so-sh & $\mathrm{S}$ \\
\hline Qt5o & $3-5$ & Flat & 6 & $90-146$ & $52-93$ & 10YR & $\bmod \mathrm{Bw}$ & sbk & so-sh & LS \\
\hline Qt4 & $5-10$ & Flat & 4 & $\begin{array}{c}286- \\
291\end{array}$ & $181-246$ & $\begin{array}{c}10- \\
8.75 \mathrm{YR}\end{array}$ & $\begin{array}{c}\text { strong } \\
\text { Bw-weak } \\
\text { Bt }\end{array}$ & sbk & so-sh & LS \\
\hline Qt3 & $20-40$ & Flat & 5 & $\begin{array}{l}240- \\
329 \\
\end{array}$ & $211-249$ & $\begin{array}{c}8.75- \\
7.5 \mathrm{YR}\end{array}$ & $\bmod \mathrm{Bt}$ & pr-sbk & sh-h & SL \\
\hline Qt2 & $30-50$ & $\begin{array}{c}\text { Ballena } \\
\text { topography }\end{array}$ & 2 & $\begin{array}{l}287- \\
290\end{array}$ & $190-210$ & $2.5 \mathrm{YR}$ & strong Bt & pr-abk & h-vh & SCL \\
\hline Qt1 & $\sim 15->20$ & $\begin{array}{c}\text { Ballena } \\
\text { topography, } \\
\text { flat surfaces }\end{array}$ & 1 & 326 & 278 & 5YR & $\begin{array}{c}\text { strong } \mathrm{Bt} \\
\text { strong } \mathrm{Bk}^{8}\end{array}$ & pr-abk & h-vh & $\mathrm{CL}$ \\
\hline
\end{tabular}

1: Total depth to top of first $\mathrm{C}$ horizon, minimum-maximum range where more than one soil

2: Thickness of B horizon (includes BC horizons), minimum-maximum range where more than one soil

3: Most rubified B horizon Munsell soil color hue

4: Best developed type of genetic B horizon ( $\mathrm{w}=$ structure/color, $\mathrm{t}=$ accumulation of clay, $\mathrm{k}=$ accumulation of carbonate); $\bmod =\operatorname{moderate}$.

5: Best developed type of soil structure ( $\mathrm{sg}=$ single grain, $\mathrm{pl}=$ platy, $\mathrm{sbk}=$ subangular blocky, abk = angular blocky, $\mathrm{pr}=$ prismatic)

6: Strongest soil consistence: $\mathrm{lo}=$ loose, $\mathrm{so}=\mathrm{soft}$, $\mathrm{sh}=$ slightly hard, $\mathrm{h}=$ hard, $\mathrm{vh}=$ very hard

7: Finest soil texture (i.e. highest concentration of silt and clay) $\mathrm{S}=$ sand, $\mathrm{LS}=$ loamy sand, $\mathrm{L}=1 \mathrm{loam}, \mathrm{SCL}=$ sandy-clay loam, $\mathrm{CL}=$ clay loam.

8: All soils except the single soil described on the Qt1 lack pedogenic carbonate; the source of carbonate in the Qt1 soil is due to in-situ medication

of marine coral deposits as the base of the soil. 
Table 1. B. Summary of catchment bedrock, sedimentological properties and the interpreted sedimentary regime for each unit.

\begin{tabular}{|c|c|c|c|}
\hline Unit & Catchment bedrock & Most common bedforms & Interpreted sedimentation regime \\
\hline Qt6 & $\begin{array}{l}\text { Gneiss and granodiorites (SJ*), granites } \\
\text { (LP*) }\end{array}$ & Horizontal planar, low angle cross bedding & Channelized flow \\
\hline Qt5y & $\begin{array}{c}\text { Gneiss and granodiorites (SJ), granites } \\
\text { (LP) }\end{array}$ & Horizontal planar, low angle cross bedding & Upper regime flow, channelized flow \\
\hline Qt5o & Gneiss and granodiorites (SJ), & Horizontal planar, low angle cross bedding & Upper regime flow \\
\hline Qt4 & Gneiss and granodiorites (SJ), & $\begin{array}{c}\text { Horizontal planar, low angle cross bedding, } \\
\text { antidunes }\end{array}$ & Upper regime flow \\
\hline Qt3 & Gneiss and granodiorites (SJ), & $\begin{array}{l}\text { Antidunes, Horizontal planar, low angle cross } \\
\text { bedding, transverse ribs (gravel bars) }\end{array}$ & Upper regime flow \\
\hline Qt2 & Gneiss and granodiorites (SJ), & $\begin{array}{c}\text { Antidunes, Horizontal planar, low angle cross } \\
\text { bedding, transverse ribs (gravel bars) }\end{array}$ & Upper regime flow \\
\hline Qt1 & $\begin{array}{l}\text { Granites (LP south), volcaniclastics (LP } \\
\text { north), gneisses (SJ) }\end{array}$ & Horizontal planar, low angle cross bedding, & Upper regime flow, channelized flow \\
\hline
\end{tabular}

(*) SJ: San José basin; LP: La Paz basin. 
Table 2. Luminescence dating results. Ages reported here as in Brown et al. (2014), adding six new samples. Unit assignments are updated based on soils data for the pits and sections linked to the samples.

\begin{tabular}{|c|c|c|c|c|c|}
\hline Site/Pit(†) & Lab ID* & Sample ID & Unit & $\begin{array}{c}\text { Dep } \\
\text { th } \\
{[\mathrm{m}]}\end{array}$ & $\begin{array}{l}\text { Age }[\mathrm{ka}] \text { and } \\
\text { uncertainty } 1 \text { s.d. }\end{array}$ \\
\hline \multicolumn{6}{|l|}{ Qt6 unit (includes 1976 Liza deposit) } \\
\hline \multirow[t]{4}{*}{ Cajoncito north section, 1976 Liza on top (CAJ-I/II) } & J0403 & BA1205 & 1976 & 0.69 & $0.1 \pm 0.1$ \\
\hline & J0404 & BA1206 & 1976 & 0.96 & $0.7 \pm 0.5$ \\
\hline & J0405 & BA1207 & 1976 & 1.63 & $0.3 \pm 0.1$ \\
\hline & J0406 & BA1208 & 1976 & 2.84 & $0.3 \pm 0.1$ \\
\hline San Lázaro channel, Qt6 & J0425 & BA1227 & Qt6 & 0.47 & $0.4 \pm 0.1$ \\
\hline \multirow[t]{2}{*}{ Arroyo San Lázaro, channel quarry, SL1 } & J0194 & SL101 & Qt6 & 0.8 & $0.4 \pm 0.1$ \\
\hline & J0195 & SL102 & Qt6 & 2.0 & $0.4 \pm 0.1$ \\
\hline \multicolumn{6}{|l|}{$\begin{array}{l}\text { Qt5 unit (includes Qt5y, Qt5o in Table 1, also } \\
\text { Qt4 in lower portions of dated sections) }\end{array}$} \\
\hline \multirow[t]{2}{*}{ Arroyo San Lázaro, section, SL4 } & J0200 & SL401 & Qt5 & 0.5 & $0.5 \pm 0.1$ \\
\hline & J0201 & SL402 & Qt5 & 0.9 & $0.4 \pm 0.1$ \\
\hline \multirow[t]{2}{*}{ San Lázaro, section, 3 m terrace N side (by SL4) } & J0423 & BA1225 & Qt5 & 0.75 & $0.5 \pm 0.1$ \\
\hline & J0424 & BA1226 & Qt5 & 0.75 & $0.3 \pm 0.05$ \\
\hline \multirow[t]{2}{*}{ EAO-4 pit } & J0129 & EAO-04-L1 & Qt5 & 1.50 & $3.3 \pm 0.7$ \\
\hline & J0130 & EAO-04-L2 & Qt5 & 1.70 & $2.4 \pm 0.6$ \\
\hline \multirow[t]{2}{*}{ El Mesquitito shell site } & J0415 & BA1217 & Qt5 & 1.17 & $6.0 \pm 1.3$ \\
\hline & J0416 & BA1218 & Qt4 & 1.95 & $9.9 \pm 2.7$ \\
\hline \multirow[t]{4}{*}{ Bonfil bank, (same site as Maloney, 2009) } & J0407 & BA1209 & Qt5 & 1.0 & $5.5 \pm 0.8$ \\
\hline & J0408 & BA1210 & Qt5 & 1.2 & $6.1 \pm 1.3$ \\
\hline & J0409 & BA1211 & Qt4 & 1.4 & $8.9 \pm 1.2$ \\
\hline & J0410 & BA1212 & Qt4 & 1.6 & $11.6 \pm 2.1$ \\
\hline \multicolumn{6}{|l|}{ Qt4 unit } \\
\hline \multirow[t]{4}{*}{ San José airport terrace, Pit SJ1 } & J0186 & SJ101 & Qt4 & 2.2 & $12.3 \pm 1.1$ \\
\hline & J0187 & SJ102 & Qt4 & 2.5 & $13.6 \pm 1.2$ \\
\hline & J0188 & SJ103 & Qt4 & 2.8 & $14.6 \pm 1.3$ \\
\hline & J0189 & SJ104 & Qt4 & 3.1 & $13.6 \pm 1.2$ \\
\hline San José airport terrace, Pit SJ2 & J0190 & SJ201 & Qt4 & 0.9 & $3.0 \pm 0.4$ \\
\hline
\end{tabular}




\begin{tabular}{|c|c|c|c|c|c|}
\hline & J0191 & SJ202 & Qt4 & 1.4 & $4.6 \pm 0.5$ \\
\hline & J0192 & SJ203 & Qt4 & 2.0 & $7.0 \pm 1.0$ \\
\hline & J0193 & SJ204 & Qt4 & 2.8 & $20.4 \pm 1.7$ \\
\hline \multirow[t]{4}{*}{ Santa Teresita terrace, Pit ST2 } & J0202 & ST201 & Qt4 & 0.7 & $1.0 \pm 0.1$ \\
\hline & J0203 & ST202 & Qt4 & 1.14 & $2.0 \pm 0.2$ \\
\hline & J0204 & ST203 & Qt4 & 1.6 & $4.8 \pm 0.5$ \\
\hline & $\mathrm{J} 0205$ & ST204 & Qt4 & 2.48 & $16.4 \pm 2.8$ \\
\hline \multirow[t]{3}{*}{ Cajoncito south section (CAJ-III) } & J0399 & BA1201 & Qt4 & 4.0 & $11.8 \pm 2.2$ \\
\hline & J0400 & BA1202 & Qt4 & 4.2 & $16.4 \pm 2.9$ \\
\hline & J0401 & BA1203 & Qt4 & 5.0 & $13.4 \pm 3.1$ \\
\hline Bonfil quarry, same site as Maloney (2009), upper section & J0412 & BA1214 & Qt4 & 2.60 & $20.7 \pm 3.7$ \\
\hline \multicolumn{6}{|l|}{ Qt3 unit } \\
\hline \multirow[t]{2}{*}{ Bonfil quarry, same site as Maloney (2009), lower section } & J0413 & BA1215 & Qt3 & 0.40 & $34.6 \pm 4.7$ \\
\hline & J0414 & BA1216 & Qt3 & 1.08 & $30.4 \pm 4.4$ \\
\hline \multirow[t]{2}{*}{ EAO-2 pit } & J0127 & EAO-02-L1 & Qt3 & 2.15 & $31.0 \pm 3.5$ \\
\hline & $\mathrm{J} 0128$ & EAO-02-L2 & Qt3 & 1.70 & $26.4 \pm 3.4$ \\
\hline CAD-3 site & BAJA1 & CAD3-1 & Qt3 & 3.00 & $35.3 \pm 1.9$ \\
\hline \multirow[t]{4}{*}{ Arroyo San Lázaro, section III (site SL3) } & J0196 & SL301 & Qt3 & 15.0 & $30.6 \pm 2.8$ \\
\hline & J0197 & SL302 & Qt3 & 15.2 & $36.4 \pm 3.6$ \\
\hline & J0198 & SL303 & Qt3 & 15.4 & $36.1 \pm 2.5$ \\
\hline & J0199 & SL304 & Qt3 & 16.3 & $37.0 \pm 2.9$ \\
\hline \multicolumn{6}{|l|}{ Qt2 unit } \\
\hline \multirow{2}{*}{$\begin{array}{l}\text { Ejido Alvaro Obregón (section below Qt3/Qt2 surface, by } \\
\text { modern channel) }\end{array}$} & $\mathrm{J} 0417$ & BA1219 & Qt2 & 5.0 & $52.2 \pm 4.8$ \\
\hline & J0418 & BA1220 & Qt2 & 6.0 & $66.5 \pm 6.8$ \\
\hline \multirow[t]{2}{*}{ Mesa del Moro terrace } & J0419 & BA1221 & Qt2 & 5.0 & $58.8 \pm 3.2$ \\
\hline & $\mathrm{J} 0420$ & BA1222 & Qt2 & 5.0 & $55.7 \pm 5.0$ \\
\hline \multirow[t]{2}{*}{ Desertica } & J0421 & BA1223 & Qt2 & 1.8 & $62.7 \pm 7.4$ \\
\hline & $\mathrm{J} 0422$ & BA1224 & Qt2 & 1.8 & $65.0 \pm 6.1$ \\
\hline EAO-3 pit & BAJA3 & EAO-07-JL1 & Qt2 & 2.70 & $57.2 \pm 4.4$ \\
\hline
\end{tabular}

$\dagger$ †ites in bold, San José basin.

* Samples J0127-0130 processed at UCLA, this study; samples BAJA1 and BAJA3 were processed and measured at DRI, this study. Samples J0186-J0424 processed and measured at UCLA and reported in Brown et al. (2014). 
Table 3. Radiocarbon data.

\begin{tabular}{|c|c|c|c|c|c|c|c|}
\hline Site/Pit & $\begin{array}{l}\text { Lab Id, } \\
\text { BETA }\end{array}$ & $\begin{array}{l}\text { Sample ID } \\
\text { and type }\end{array}$ & Unit & $\begin{array}{l}\text { Depth } \\
{[\mathrm{m}]}\end{array}$ & $\begin{array}{l}\text { Conventional age } \\
(\mathrm{BP}, \mathrm{pMC}) \text { and } \\
\text { uncertainty }\end{array}$ & $\delta^{13} \mathrm{C}$ & $\begin{array}{c}\text { Calibrated age } 2 \text { sigma range and } \\
\text { probability }(*)\end{array}$ \\
\hline \multirow[t]{2}{*}{$\begin{array}{l}\text { Cajoncito, } \\
\text { Liza } 1976\end{array}$} & 279501 & $\begin{array}{l}\text { CAJ003, } \\
\text { bone }\end{array}$ & Qt6 & 1.61 & $160.9 \pm 0.4 \mathrm{pMC}$ & -18.3 & \multirow{2}{*}{$\begin{array}{l}\text { [cal AD 1963.29 :cal AD 1963.35] } 0.033 \\
\text { [cal AD 1966.95 :cal AD 1968.21] 0.866 } \\
\text { [cal AD 1968.56 :cal AD 1968.71] } 0.101 \\
\text { [cal AD 1962.80 :cal AD 1963.03] } 0.128 \\
\text { [cal AD 1971.51 :cal AD 1971.55] } 0.008 \\
\text { [cal AD 1972.26 :cal AD 1972.29] } 0.003 \\
\text { [cal AD 1972.96 :cal AD 1974.88] 0.860 }\end{array}$} \\
\hline & 279502 & $\begin{array}{l}\text { CAJ004, } \\
\text { bone }\end{array}$ & Qt6 & 2.64 & $144.4 \pm 0.5 \mathrm{pMC}$ & -19.8 & \\
\hline \multirow[t]{3}{*}{$\begin{array}{l}\text { Mesquitito, } \\
\text { shell site }\end{array}$} & 279503 & $\begin{array}{l}\text { CAJ005, } \\
\text { charred } \\
\text { material }\end{array}$ & Qt5 & 0.77 & $90 \pm 40$ & -28.3 & 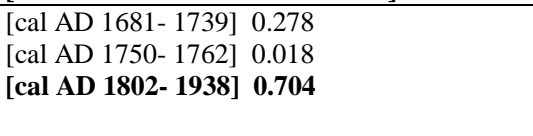 \\
\hline & 279504 & $\begin{array}{l}\text { CAJ006, } \\
\text { shell }\end{array}$ & Qt5 & 1.00 & $4790 \pm 40$ & +1.6 & [cal BP 4596 - 4839] 1.000 \\
\hline & 279505 & $\begin{array}{l}\text { CAJ007, } \\
\text { charred } \\
\text { material }\end{array}$ & Qt5 & 1.07 & $108.7 \pm 0.4 \mathrm{pMC}$ & -26.1 & $\begin{array}{l}\text { [cal AD 1957.51:cal AD 1958.08] } 0.069 \\
\text { [cal AD 1999.17 :cal AD 1999.41] } 0.015 \\
\text { [cal AD 1999.92 :cal AD 2003.10] 0.895 } \\
\text { [cal AD 2003.34 :cal AD 2003.80] } 0.020\end{array}$ \\
\hline
\end{tabular}

(*) Calibrated with INTCAL13 database (Reimer et al., 2013), both before 1950 and after 1950 using North Hemisphere Zone 2 data

(Hua et al., 2013). Preferred age range in bold. 
Table 4. Cosmogenic ${ }^{10} \mathrm{Be}$ depth profile data.

\begin{tabular}{|c|c|c|c|c|c|c|c|c|}
\hline Sample Id & $\begin{array}{c}\text { Depth } \\
{[\mathrm{cm}]}\end{array}$ & $\begin{array}{c}\text { Thickness } \\
{[\mathrm{cm}]}\end{array}$ & $\begin{array}{c}\text { Dissolved } \\
\text { mass }[\mathrm{g}]\end{array}$ & $\begin{array}{c}\text { Carrier } \\
\text { mass }^{\mathrm{a}} \\
{[\mathrm{g}]}\end{array}$ & $\begin{array}{c}\text { Corrected } \\
\text { for } \\
\text { blank }{ }^{10} \mathrm{Be} / \\
{ }^{9} \mathrm{Be}\end{array}$ & $\begin{array}{c}{ }^{10} \mathrm{Be} \\
\text { concentration } \\
\text { [atom } / \mathrm{g}]\end{array}$ & $\begin{array}{c}\text { AMS } \\
\text { uncertainty }\end{array}$ & $\begin{array}{c}\text { Total }^{\mathrm{b}} \\
\text { uncertainty }\end{array}$ \\
\hline EAO0201 & 250 & 10 & 70.6706 & 1.0155 & $4.14 \mathrm{E}-13$ & $1.083 \mathrm{E}+05$ & $8.5 \%$ & $9.8 \%$ \\
\hline EAO0202 & 200 & 7 & 53.3308 & 0.9820 & $3.60 \mathrm{E}-13$ & $1.205 \mathrm{E}+05$ & $2.0 \%$ & $5.3 \%$ \\
\hline EAO0204 & 115 & 5 & 66.3264 & 1.0103 & $7.48 \mathrm{E}-13$ & $2.074 \mathrm{E}+05$ & $17.0 \%$ & $17.7 \%$ \\
\hline EAO0205 & 95 & 4 & 51.4976 & 0.9890 & $5.16 \mathrm{E}-13$ & $1.803 \mathrm{E}+05$ & $2.0 \%$ & $5.3 \%$ \\
\hline EAO0206 & 76 & 5 & 49.6240 & 1.0024 & $5.23 \mathrm{E}-13$ & $1.924 \mathrm{E}+05$ & $2.0 \%$ & $5.3 \%$ \\
\hline EAO0207 & 61 & 5 & 50.6857 & 1.0041 & $5.52 \mathrm{E}-13$ & $1.991 \mathrm{E}+05$ & $2.0 \%$ & $5.3 \%$ \\
\hline EAO0208 & 46 & 6 & 50.4136 & 0.9783 & $5.39 \mathrm{E}-13$ & $1.903 \mathrm{E}+05$ & $2.0 \%$ & $5.3 \%$ \\
\hline EAO0209 & 31 & 5 & 50.1676 & 0.9991 & $5.30 \mathrm{E}-13$ & $1.921 \mathrm{E}+05$ & $2.0 \%$ & $5.3 \%$ \\
\hline EAO0301 & 313 & 14 & 34.4286 & 0.9707 & $1.50 \mathrm{E}-13$ & $7.681 \mathrm{E}+04$ & $2.0 \%$ & $5.3 \%$ \\
\hline EAO0302 & 254 & 8 & 16.8939 & 0.9843 & $7.77 \mathrm{E}-14$ & $8.233 \mathrm{E}+04$ & $2.0 \%$ & $5.3 \%$ \\
\hline EAO0303 & 204 & 7 & 41.5267 & 0.9639 & $2.04 \mathrm{E}-13$ & $8.634 \mathrm{E}+04$ & $2.0 \%$ & $5.3 \%$ \\
\hline EAO0304 & 175 & 7 & 51.2987 & 0.9839 & $2.60 \mathrm{E}-13$ & $9.081 \mathrm{E}+04$ & $2.0 \%$ & $5.3 \%$ \\
\hline EAO0305 & 149 & 6 & 41.4480 & 0.9832 & $2.30 \mathrm{E}-13$ & $9.941 \mathrm{E}+04$ & $10.0 \%$ & $11.3 \%$ \\
\hline EAO0306 & 133 & 7 & 41.6932 & 0.9733 & $2.42 \mathrm{E}-13$ & $1.028 \mathrm{E}+05$ & $2.0 \%$ & $5.3 \%$ \\
\hline EAO0307 & 111 & 7 & 43.4100 & 0.9838 & 4.39E-13 & $1.810 \mathrm{E}+05$ & $10.0 \%$ & $11.3 \%$ \\
\hline EAO0308 & 95 & 7 & 26.3019 & 0.9929 & $2.15 \mathrm{E}-13$ & $1.478 \mathrm{E}+05$ & $2.0 \%$ & $5.3 \%$ \\
\hline
\end{tabular}

(a) Mass of Be carrier solution added, at a density of $1.01 \mathrm{~g} / \mathrm{ml}$, with Be concentration= $275 \mathrm{micrograms} / \mathrm{mililiter}$.

(b) Used in the modeling input parameters; obtained adding in quadrature 5\% uncertainty from reproducibility of Be-10 measurements after chemistry procedures at Dalhousie. 
Table 5. Depth profile age model ${ }^{\mathrm{a}}$ results.

\begin{tabular}{lcccrc}
\hline Profile Id & $\begin{array}{c}\text { Age } \\
{[\mathrm{ka}]}\end{array}$ & $\begin{array}{c}\text { Uncertainty } \\
\text { 2-sigma [ka] }]\end{array}$ & $\begin{array}{c}\text { Inheritance } \\
{\left[10^{5} \mathrm{at} / \mathrm{g}\right]}\end{array}$ & $\begin{array}{c}\text { Uncertainty } \\
2 \text {-sigma } \\
{\left[10^{5} \mathrm{at} / \mathrm{g}\right]}\end{array}$ & $\mathrm{n}^{\mathrm{b}}$ \\
\hline EAO-2 & 37.1 & +13 & 1.087 & +0.184 & 1000000 \\
& & -12 & & -0.223 & \\
\hline EAO-3 & 57.6 & +19 & 0.667 & +0.116 & 1000000 \\
& & -17 & & -0.098 & \\
\hline
\end{tabular}

(a) Depth Profile Model Matlab code (Hidy et al., 2010), version 1.2. Production rate at the sites computed using the CRONUS calculator version 2.2 (Balco et al, 2008). Error in total production rate for model: 20\%. Error in half-life of Be-10: 2\%. Mean attenuation length for neutrons: $160 \pm 5 \mathrm{~g} / \mathrm{cm}^{2}$.

(b) Number of runs of the model. 


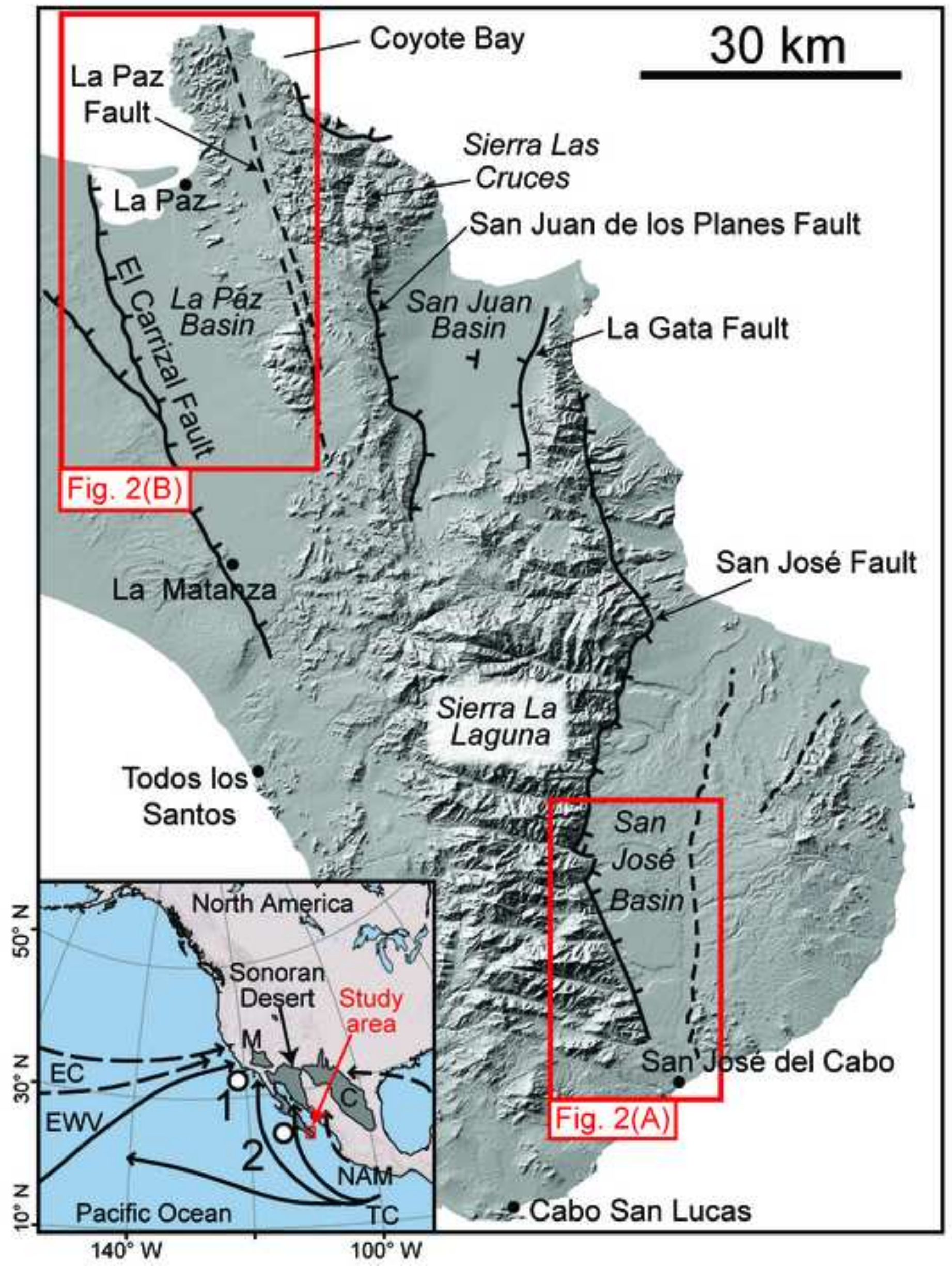


Figure 2

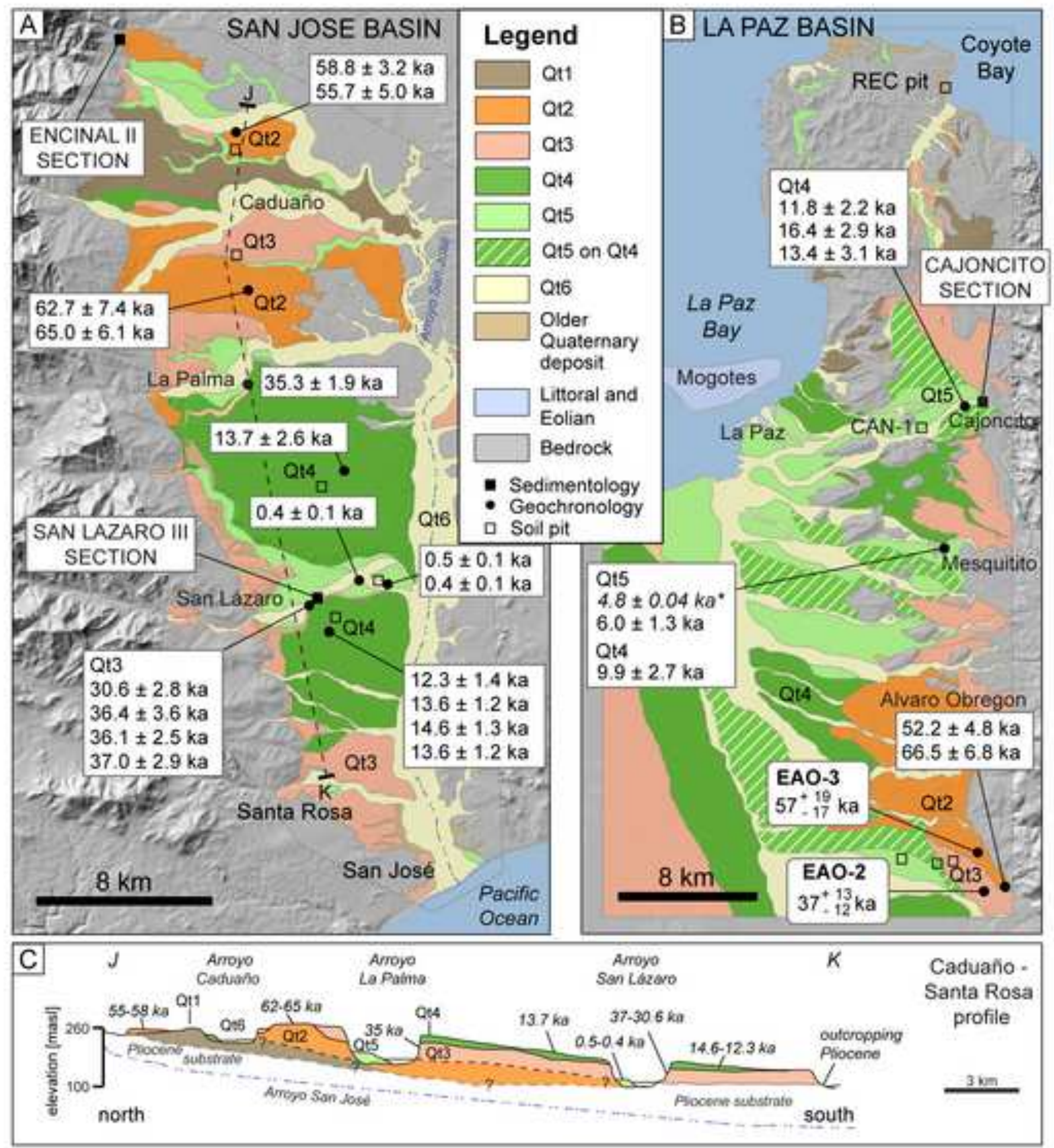




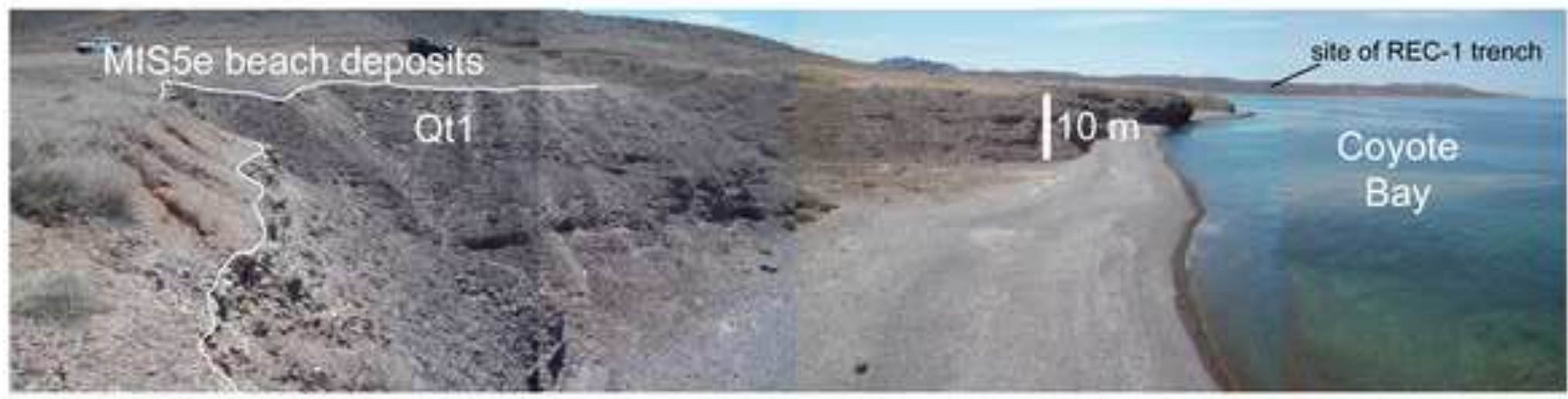

A
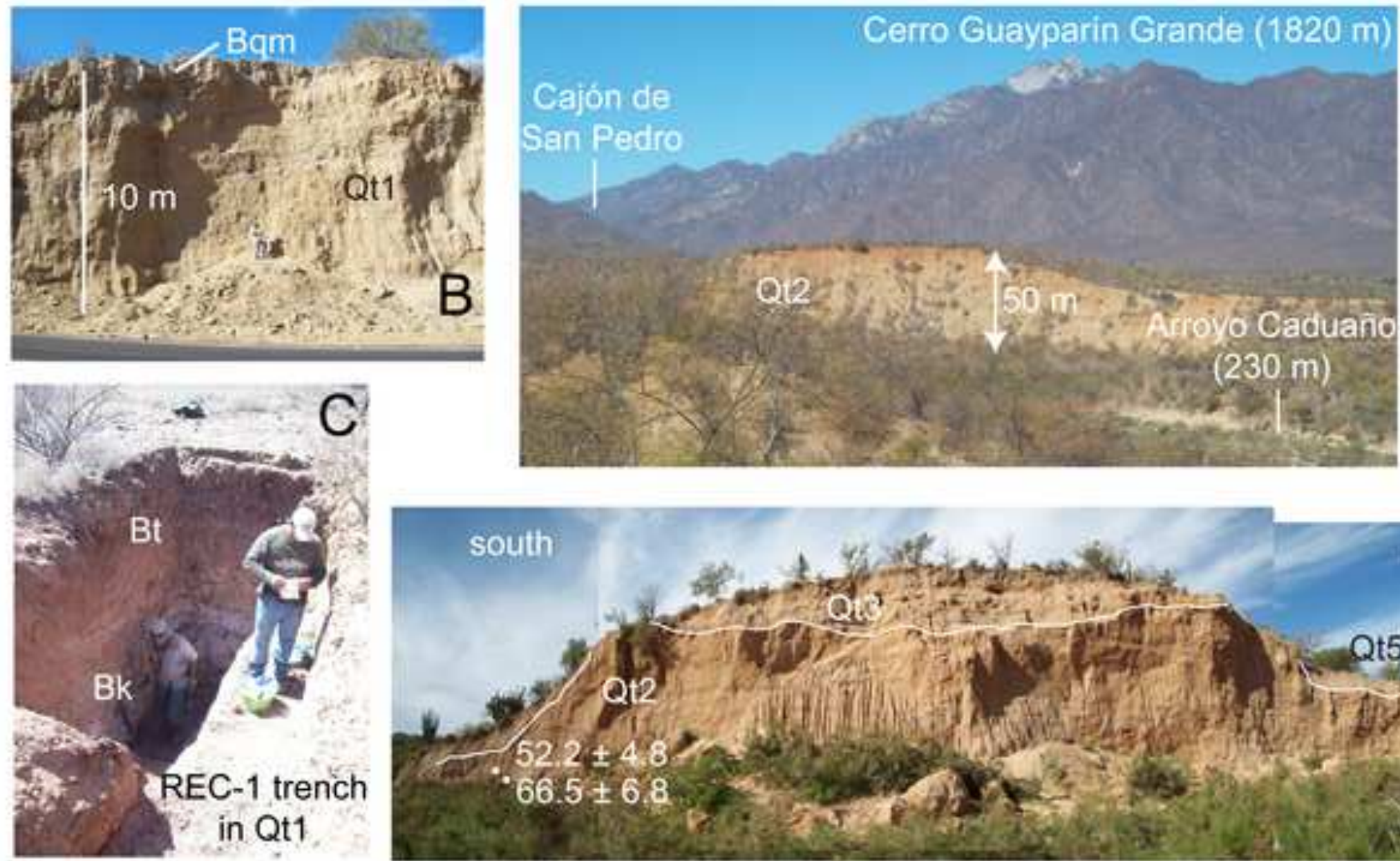

south

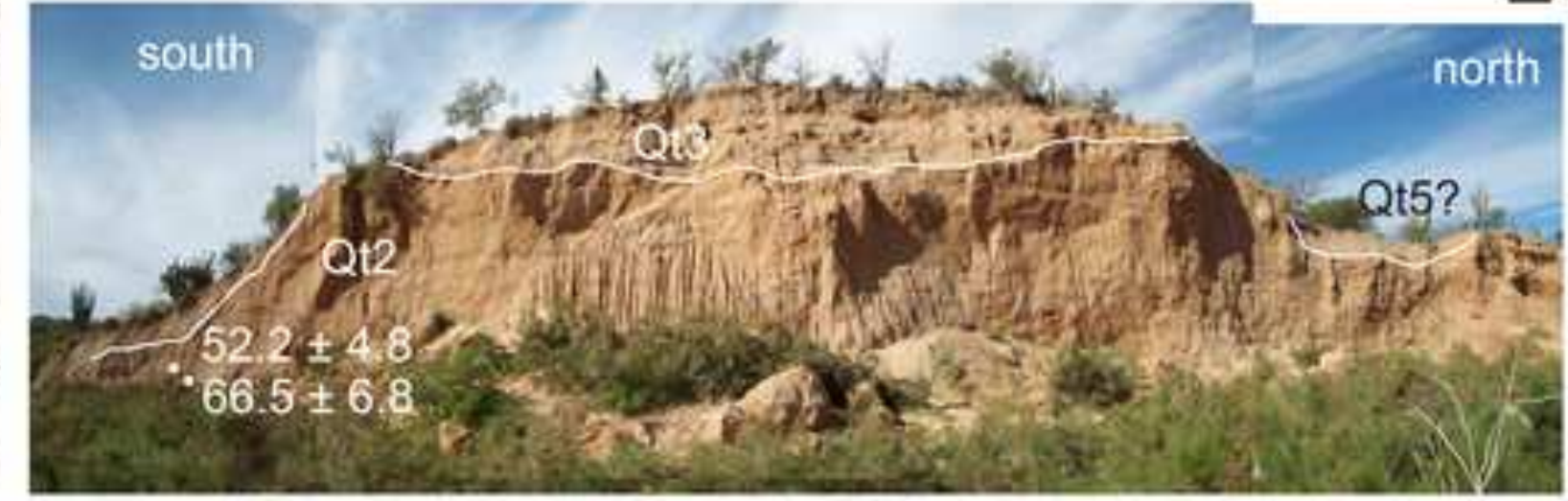

\section{E}

orth . 


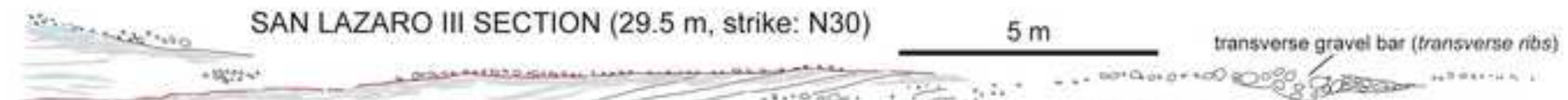

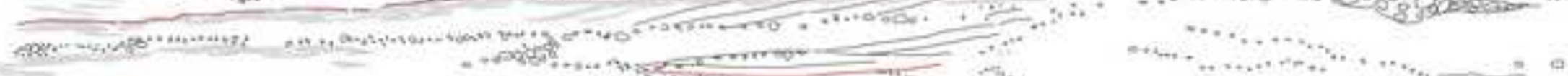
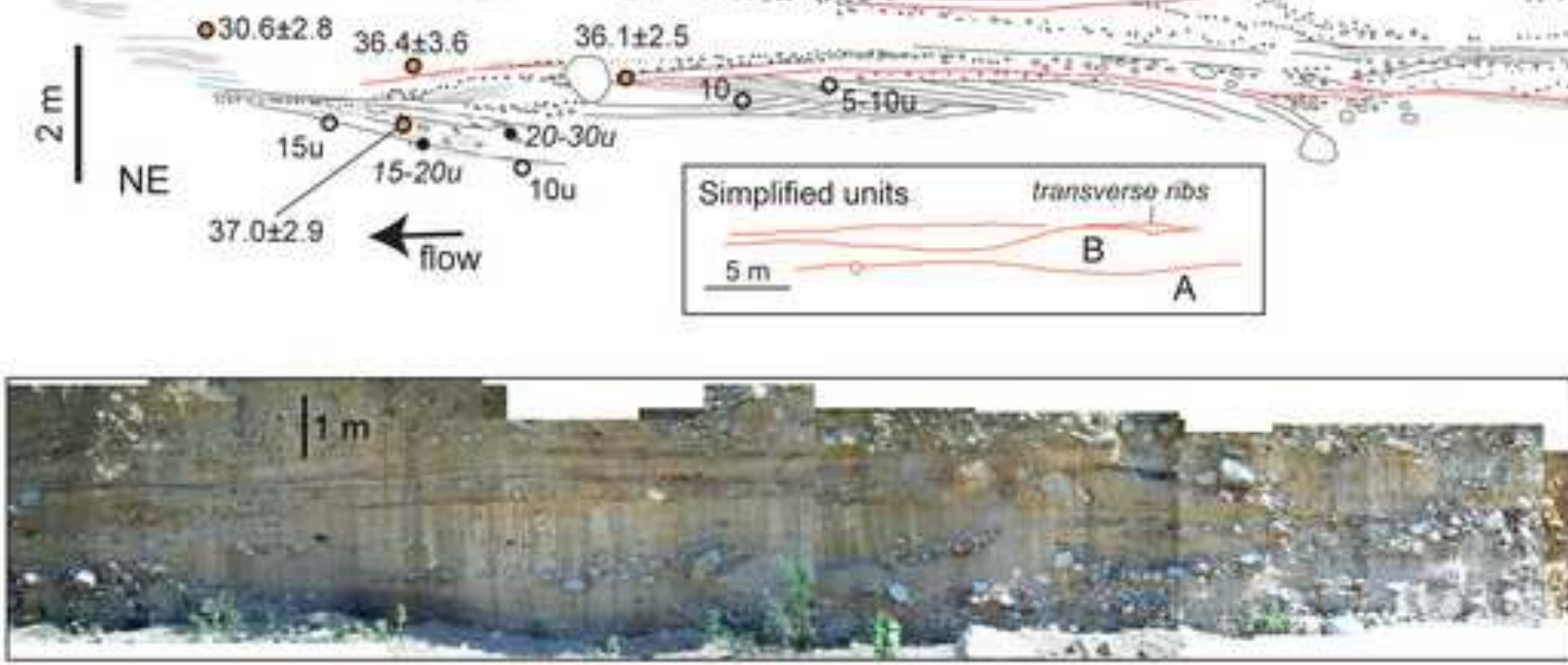

Massive-coarse boddin

0

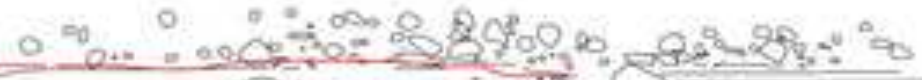

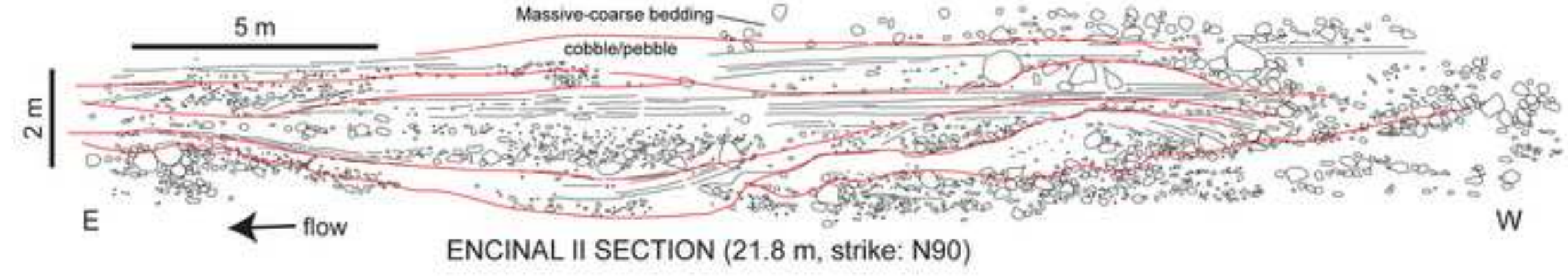

ENCINAL II SECTION (21.8 m, strike: N90)

\section{LEGEND} otherwise downstream

010 Bed apparent dip, u. upstream. otherwise downstream

08 Boulders

2.- Coarse layers, sandy gravel $-5-15 \mathrm{~mm}$ Sandy gravel horizons $0.5-5 \mathrm{~mm}$ Fine horizons, $0.25 .2 \mathrm{~mm}$ sand

Simplified units

- 20u Imbrication, dip, u: upstream. 

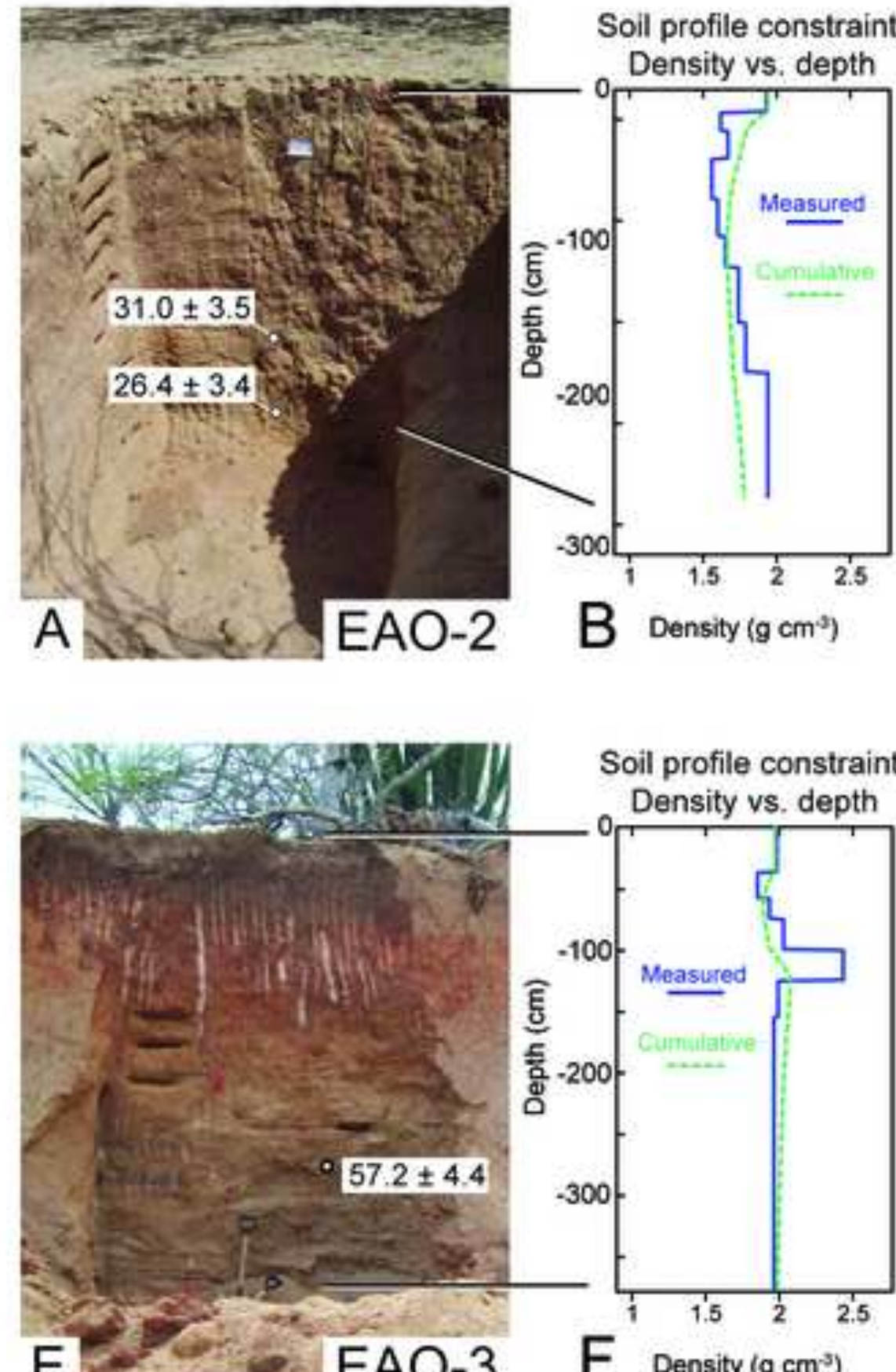
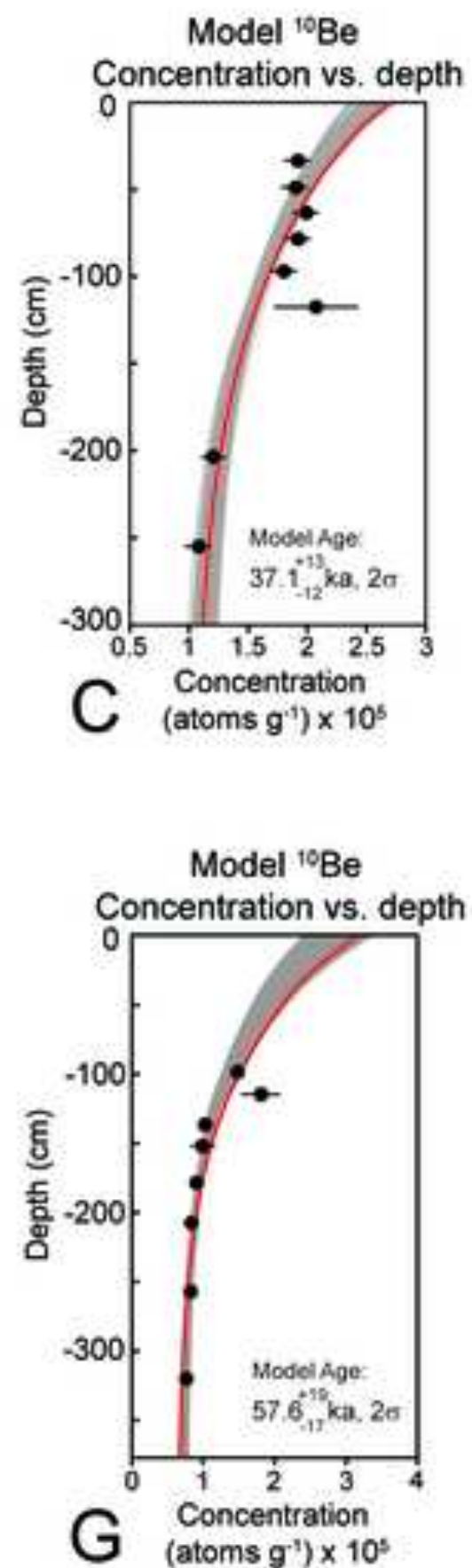

Monte Carlo Analysis

$$
n=10^{6}
$$

Probability density function

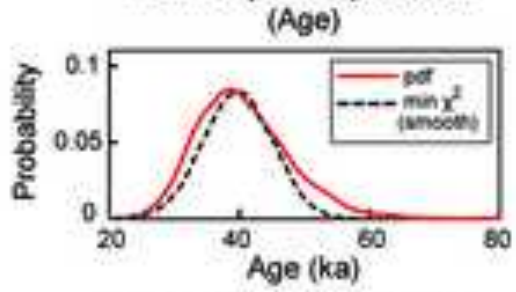

Probability density function

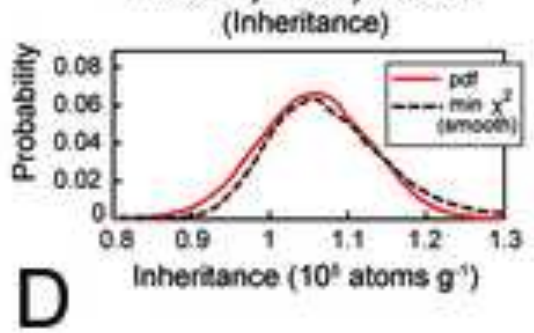

Monte Carlo Analysis $\mathrm{n}=10^{6}$

Probability density function

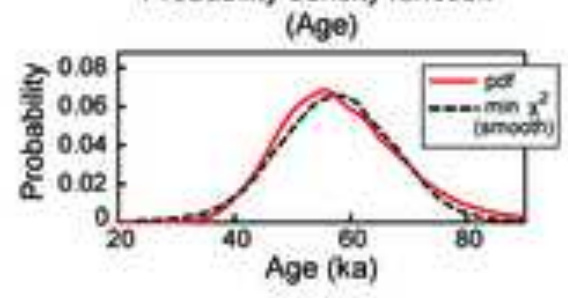

Probability density function (inheritance)

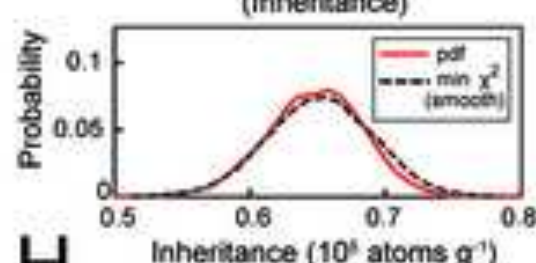

$\mathrm{H}$ 

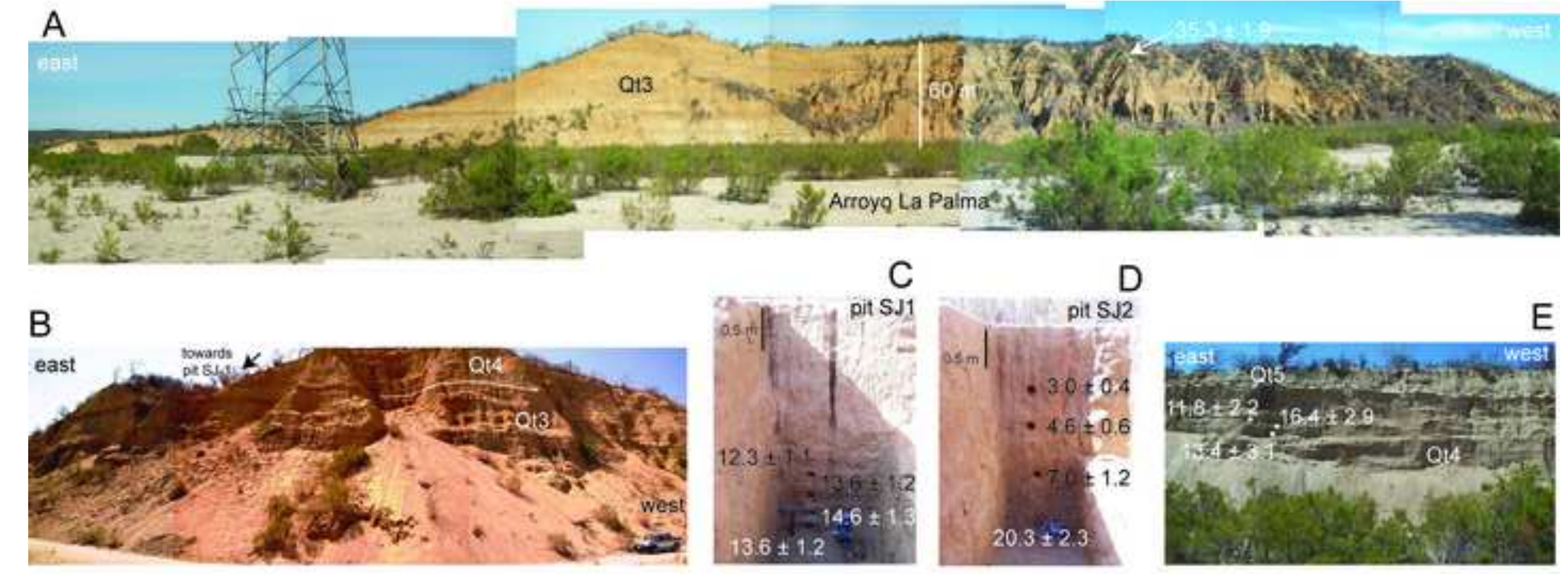

E

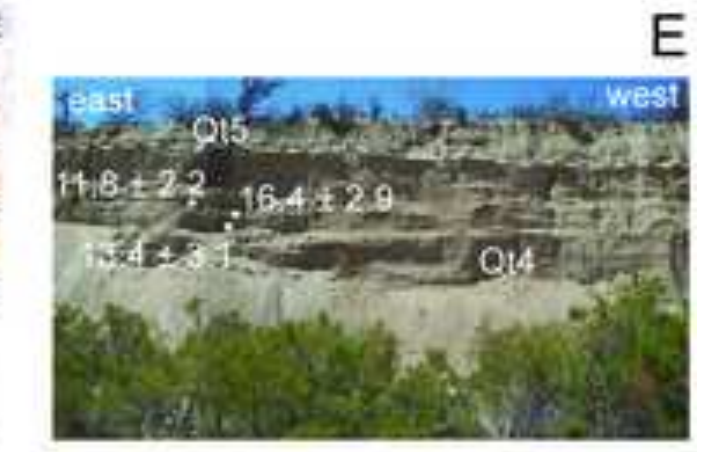

D 

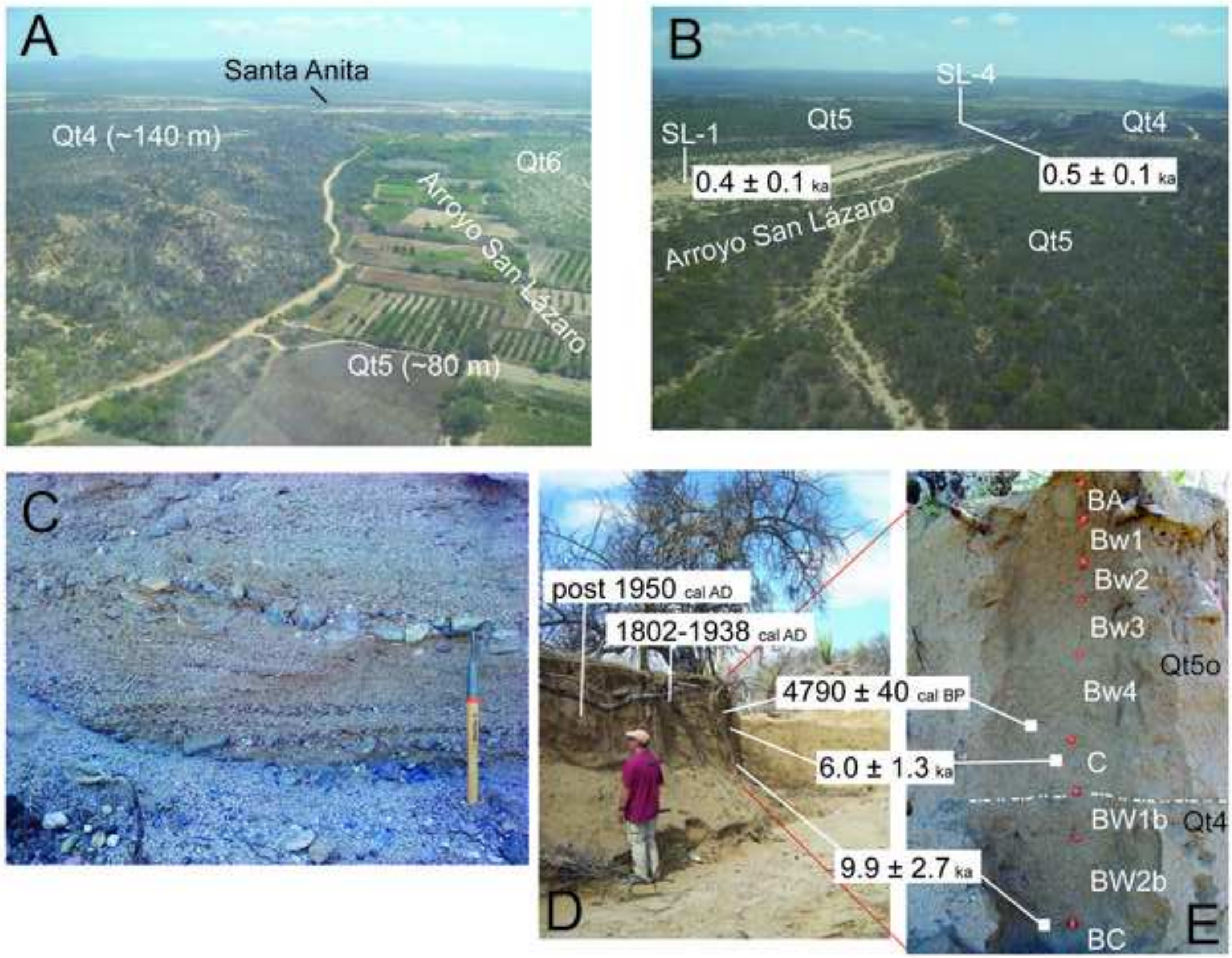


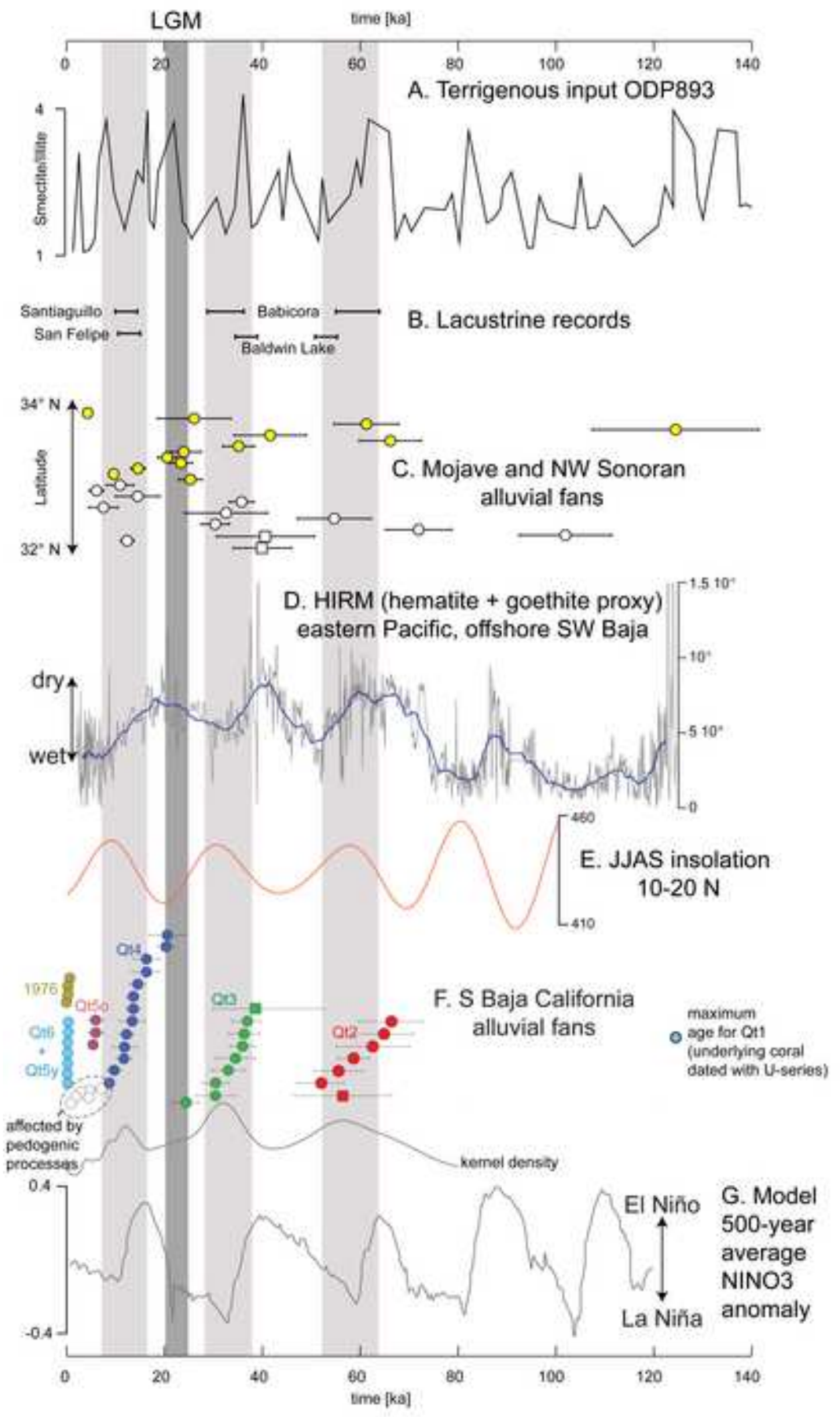

